\title{
Process Options Description for Steam Reforming Flowsheet Model of INEEL Tank Farm Waste
}

\author{
D. D. Taylor \\ C. M. Barnes \\ T. T. Nichols
}

May 2002

Idaho National Engineering and Environmental Laboratory Bechtel BWXT Idaho, LLC 
INEEL/EXT-02-00545

Revision 0

\title{
Process Options Description for Steam Reforming Flowsheet Model of INEEL Tank Farm Waste
}

\author{
Dean D. Taylor \\ Charles M. Barnes \\ Todd T. Nichols
}

May 2002

Idaho National Engineering and Environmental Laboratory High Level Waste Program Idaho Falls, Idaho 83415

Prepared for the

U.S. Department of Energy

Assistant Secretary for Environmental Management

Under DOE Idaho Operations Office

Contract DE-AC07-99ID13727 


\section{DISCLAIMER}

This information was prepared as an account of work sponsored by an agency of the U.S. Government. Neither the U.S. Government nor any agency thereof, nor any of their employees, makes any warranty, express or implied, or assumes any legal liability or responsibility for the accuracy, completeness, or usefulness of any information, apparatus, product, or process disclosed, or represents that its use would not infringe privately owned rights. References herein to any specific commercial product, process, or service by trade name, trademark, manufacturer, or otherwise, does not necessarily constitute or imply its endorsement, recommendation, or favoring by the U.S. Government or any agency thereof. The views and opinions of authors expressed herein do not necessarily state or reflect those of the U.S. Government or any agency thereof. 


\section{ABSTRACT}

Technical information is provided herein that is required for development of a steady-state process simulation of a baseline steam reforming treatment train for Tank Farm waste at the Idaho National Engineering and Environmental Laboratory (INEEL). This document supercedes INEEL/EXT-2001-173, produced in FY2001 to support simulation of the direct vitrification treatment train which was the previous process baseline. A process block flow diagram for steam reforming is provided, together with a list of unit operations which constitute the process. A detailed description of each unit operation is given which includes its purpose, principal phenomena present, expected pressure and temperature ranges, key chemical species in the inlet stream, and the proposed manner in which the unit operation is to be modeled in the steady state process simulation. Models for the unit operations may be mechanistic (based on first principles), empirical (based solely on pilot test data without extrapolation), or by correlations (based on extrapolative or statistical schemes applied to pilot test data). Composition data for the expected process feed streams is provided. 


\section{CONTENTS}

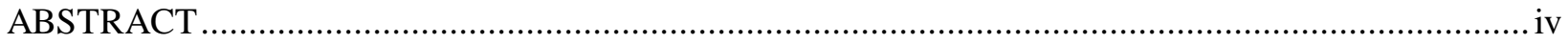

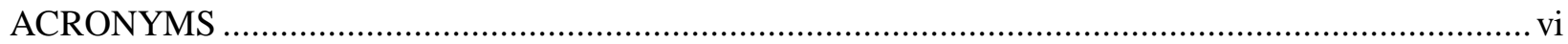

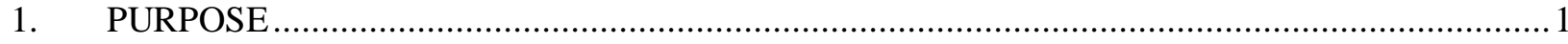

2. SCOPE

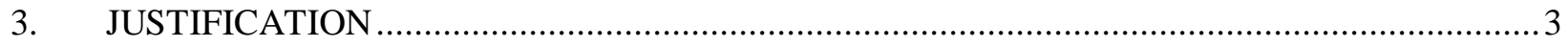

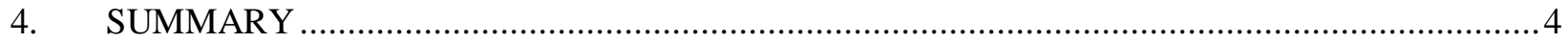

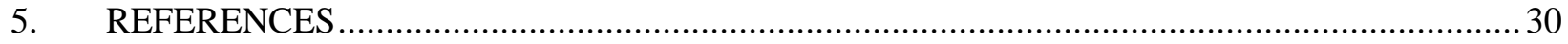

FIGURES

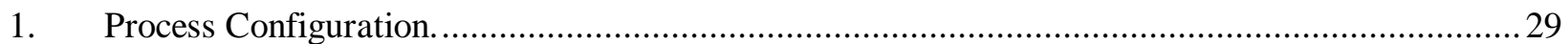

\section{TABLES}

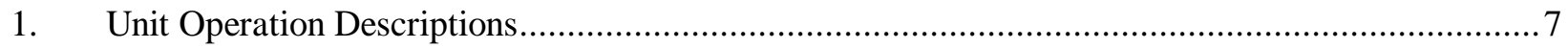

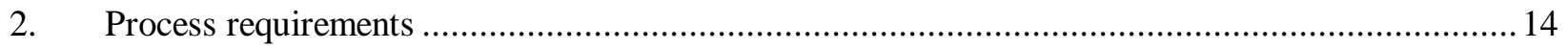

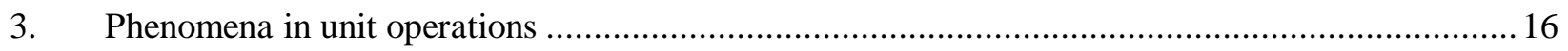

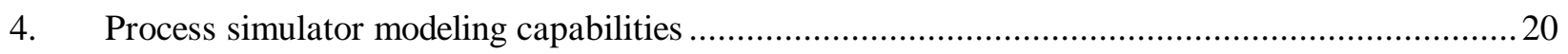

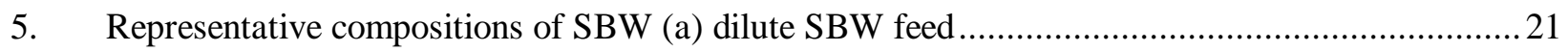

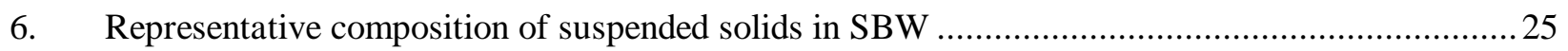

7. Representative compositions of heel solids from SBW Tanks.....................................................26

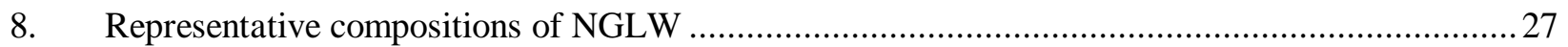

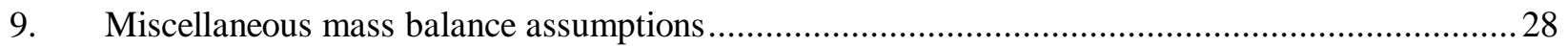




\section{ACRONYMS}

$\begin{array}{ll}\text { FS } & \text { Flowsheet } \\ \text { FY } & \text { Fiscal Year } \\ \text { INEEL } & \text { Idaho National Engineering and Environmental Laboratory } \\ \text { INTEC } & \text { Idaho Nuclear Technology and Engineering Center (at INEEL) } \\ \text { LLW } & \text { Low Level Waste } \\ \text { MB } & \text { Mass Balance } \\ \text { PM } & \text { Particulate Matter } \\ \text { SR } & \text { Steam reformer (or Steam Reforming) } \\ \text { TFA } & \text { Tanks Focus Area } \\ \text { TFF } & \text { Tank Farm Facility } \\ \text { TTP } & \text { Technical Task Plan } \\ \text { V/L/S } & \text { Vapor/Liquid/Solid } \\ \text { WIPP } & \text { Waste Isolation Pilot Plant }\end{array}$




\section{Process Options Description for Steam Reforming Flowsheet Model of INEEL Tank Farm Waste}

\section{PURPOSE}

The purpose of this document is to provide the technical information that is required for the development of a basic steady-state process simulation of the steam reforming treatment train for Tank Farm waste at the Idaho National Engineering and Environmental Laboratory (INEEL). INEEL considers simulation to have an important role in the integration/optimization of treatment process trains for the High Level Waste (HLW) Program. During FY2001 this project involved a joint Technical Task Plan (TTP ID77WT31, Subtask C) between the Savannah River Site (SRS) and the INEEL. However, as a result of DOE redirection of INEEL's development program away from vitrification the SRS work scope supporting simulation of INEEL's treatment process has been eliminated. 


\section{SCOPE}

This document provides information needed for process simulation engineers to construct and link unit operation models in a commercial process simulator to represent the treatment train for the steam reforming of SBW. The information supplied is of a mid- to high-level nature and consists of the following:

1. A list of specific unit operations, their probable operating conditions and constraints, and applicable modeling approaches for FY-2002 (see Tables 1-4);

2. One potential process configuration of the steam reforming treatment train showing the component unit operations and their interdependencies via stream connections (see Figure 1); and

3. Stream compositional makeups (see Table 5-9).

Low-level information, such as assumed species partition fractions or separation efficiencies, is not detailed in this document because it is not required for the construction and verification of the simulation package. This document is focused only on a steady-state simulation of steam reforming treatment of Tank Farm waste to be assembled in FY-2002. In addition, per the current assumed scope of activities by the HLW program at INEEL, the treatment of solid calcine will be separate from treatment of Tank Farm waste and will neither be modeled as part of this effort nor will it be included within the scope of this document. Tank Farm waste includes sodium bearing waste (SBW), newly generated liquid waste (NGLW), tank heels, and tank solids. 


\section{JUSTIFICATION}

The reason for building a simulation model for steam reforming in a commercial process simulator is to provide mass balance accounting to support INEEL HLW Program planning. Modeling of INEEL SBW treatment processes has been done in the past using linked EXCEL spreadsheets which lack a physical properties database. The objective for FY-2002 is to continue the transition away from the spreadsheet-based simulation toward a full-fledged commercial simulation software package with thermodynamic simulation capability based on a physical properties database. This package will be used to perform basic mass and heat balances on individual unit operations and around the entire treatment train. Having an integrated model with a thermodynamic database will increase the ability of INEEL engineers to assess system-wide impacts of changes to individual unit operations.

A process simulation capability is expected to facilitate process design and thus reduce life-cycle schedule and cost for the SBW treatment project, which is imperative given the 1995 Settlement Agreement commitments and shrinking DOE budgets. The fact that funding may not be available for an integrated pilot plant demonstration of the treatment train increases the likely role of process simulation. Refinements to the physical properties database and unit operation models are planned during out-years to support future optimization efforts and detailed design of SBW treatment.

Simulation results will be used by engineers and scientists to develop high-level recommendations for DOE-ID and INEEL program managers regarding the treatment of Tank Farm waste. As such, it is expected that technical personnel will be the primary end-users of the simulation results, and program management will be an indirect end-user. 


\section{SUMMARY}

Treatment of SBW stored in the Tank Farm Facility (TFF) at the Idaho Nuclear Technology and Engineering Center (INTEC) at the INEEL is a priority for the Department of Energy under the 1995 Settlement Agreement with the State of Idaho. Several options to treat this waste for disposal have been considered. During FY2001 Bechtel BWXT Idaho was directed to develop a vitrification flowsheet for SBW. However, this direction was altered at the start of FY2002 and vitrification has been supplanted with other treatment options. One option currently under DOE consideration is stream reforming (SR) of the SBW followed by packaging of the solid product for disposal at WIPP. Because steam reforming is now considered a major contender for treating the waste, the focus of this TTP was changed at the direction of TFA from vitrification to steam reforming, and simulation efforts have been re-targeted to support the latter option.

An essential first step in developing any process is to establish a flowsheet (FS) and mass balance (MB). The FS/MB describes the expected behavior of all sub-processes together with the assumptions, requirements, inputs, constraints, and known facts about the process on which the calculations in the MB are based. Thus, the flowsheet and its supporting data provide a design basis for conceptual design. The main objectives in generating the FS/MB are as follows:

a. Identify all required process input and output streams;

b. Track components of interest in the input streams through the process, partitioning them among possible output streams from the unit operations constituting the overall process;

c. Describe where each component exits the process--i.e., how much of each input component leaves in each of the output streams.

d. Describe the form (or forms) in which each input component leaves the process--i.e., what chemical compounds are formed.

e. Determine stream flowrates and properties needed for equipment sizing.

f. Determine heating and cooling requirements.

The above information constitutes a basis for process design. The MB is used to assess the adequacy of the process in transforming the inputs into the desired outputs and allows the characteristics of the output streams (e.g., flow rates, compositions, temperatures, pressures, etc.) to be compared with the process requirements. The MB is also used to provide performance specifications used to select and size the unit operations (e.g., required throughputs, required separation or reaction efficiencies, required temperatures, etc.). Both these uses of the MB assume that the information provided in items a-f above is credible for the assumed inputs and unit operations. If the underlying information is not credible then the resulting process design may not be viable.

The information required in items a-f above may be generated using any combination of the following modeling methods:

Mechanistic. Accurate models based on first principles are used to simulate the unit operations and the underlying physical and chemical phenomena. The models for the process unit operations are based on the assumed input streams and provide realistic and credible predictions for items a-f without the need for testing. 


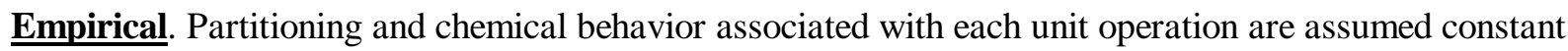
and independent of operating conditions and stream compositions. Data from bench/pilot/full scale tests is directly incorporated in ad hoc fashion to force consistency between model predictions and experimental measurements. The information produced for items a-f will be credible to the extent that the assumed performance parameters are truly independent of variation in operating conditions. Information generated using this method offers the highest credibility (albeit at the highest cost) when the scale of pilot testing approaches that of the actual production system. However, the credibility is low if pilot testing is performed only at a reduced scale (and correspondingly reduced cost), since scale effects may not then be recognized and duly accounted for.

Correlation. Empirical test data is used to formulate semi-mechanistic models that capture the influences of key operating parameters on system performance. These models are used to predict partitioning and chemical transformations in the actual system from pilot scale measurements. Such models range from simple linear regressions to statistical models and engineering correlations based on dimensional analysis. The credibility of the resulting predictions for items a-f is usually between that of the Mechanistic method and the Empirical method applied with only subscale test data.

A commercial simulator will be used to generate the MB for treatment of SBW, and the model will be updated (as needed) from time to time. In modeling the behavior of the overall process, each unit operation (or subprocess) will be represented in some fashion by one of the above modeling methods [Mechanistic, Empirical, or Correlation]. The choice of the method will be made based on the following considerations:

- What are the requirements for the process? (e.g., component "C1" of the SBW feed must leave the process in output streams "S1" and "S2", in form "Z", below a concentration of "x");

- What information should the MB provide in determining whether the process requirements are met? (e.g., the concentration of component "C3" in output stream "S4" is "x" which satisfies requirement "R1");

- What predictive capabilities does the simulator have that are applicable to the preceding bullet;

- What empirical data will be available? (e.g., what scale(s) and type(s) of testing will be performed that will provide performance data for each component of the offgas system over a representative range of inputs.)

The above considerations have led to tentative conclusions regarding how the SR process will be modeled. The rationale underlying these conclusions is captured in Tables $1-4$, below. Table 1 lists the component unit operations for the current baseline SR process shown in Figure 1. The numbers in the process boxes in the figure refer to the unit operations as listed in Table 1. For each unit operation Table 1 includes the information listed below and refers to supporting information in Tables 2-4:

Purpose: $\quad$ The function of the unit operation in the overall process scheme

Op Range: The range of temperature and pressure over which the unit operation may be expected to operate within the process

Phases: $\quad$ Physical phases (gas, solid, etc.) expected to be present in the streams entering and/or leaving the unit operation 
Phenomena: Basic phenomena that occur in the unit operation and that determine its performance. The phenomena are shaded, indicating that they are described more fully in Table 3.

Needed info: Information about the inputs/outputs of a unit operation which are of interest for (a) assessing whether the process requirements will be satisfied, and (b) designing or specifying the equipment for the unit operation

Species of int: Key chemical species in the input stream(s) to the unit operation which are expected to be altered in some way (e.g., extracted, changed chemical form, etc.) by the unit operation

Related req'ts: Process requirements likely to be impacted by the unit operation. The process requirements are shaded, indicating that they are described more fully in Table 2.

Model descr: Entries describe how the needed information will be obtained from the process simulator. The following information is given:

- A brief description of the tasks the model is to perform,

- $\quad$ Specific capabilities of the process simulator that will be used. These capabilities are shaded, indicating that they are taken from Table 4.

[Note: Table 4 describes the simulator capabilities to be employed in the FY2002 SR process model. For each simulator capability the table indicates which of the three modeling methods is used (Mechanistic, Empirical, or Correlation). None of the simulator capabilities listed in Table 4 employ the Correlation method because the needed correlative information is currently unavailable. This method is likely to be employed in the future, however, once the required data is generated.]

Representative compositional makeups of the expected feed streams for the process are given in Tables 5-9. The compositional data provided corresponds to the information needed to assess whether process requirements are met and to choose target disposal sites for all waste products.

Table 9 also gives additional assumptions that will be employed in the simulation beyond what is provided in Table 1. 
Table 1. Unit Operation Descriptions.

\section{SBW Tank}

Purpose: $\quad$ Mix SBW (1-3 tank wastes, including UDS)

Op Range: $\quad 10-33^{\circ} \mathrm{C}$, ambient pressure

Phases: $\quad$ Aqueous, solid

Phenomena: Solid/liquid chemical equilibrium

Salts form from combinations of species of interest (and minor species in feed). Soluble complexes of F-, Cl- form with spe

Needed info: (1) Composition of feed to Mixing Tank, (2) Average concentrations of $\mathrm{H}+\mathrm{Cl}$ - and $\mathrm{HF}$ in tank for corrosion rate estimates Identities and quantities of solids likely to precipitate (these may include $\mathrm{Al}, \mathrm{As}, \mathrm{Fe}, \mathrm{F}, \mathrm{Mo}, \mathrm{Na}, \mathrm{NO} 3, \mathrm{P}, \mathrm{PO} 4, \mathrm{SO} 4, \mathrm{SiO} 2$, 2 Patterson (1999)]) for assessment of blending scenarios and required equipment/piping sizing (blending equipment needed

Species of int: $\mathrm{HF}, \mathrm{H}, \mathrm{Cl}, \mathrm{Al}, \mathrm{Fe}, \mathrm{F}, \mathrm{Mo}, \mathrm{Na}, \mathrm{K}, \mathrm{NO} 3, \mathrm{P}, \mathrm{PO} 4, \mathrm{SO} 4, \mathrm{Zr}$

Related Req'ts: Feed Blending, Corrosion Allowance, Prevention of Criticality

Model descr: Blended composition of tank to next downstream component calculated as pass through using measured concentrations of $\mathrm{s}$ tanks. Mixing is assumed perfect. (Use "Mass Accounting" model.). Concentrations of $\mathrm{H}+, \mathrm{Cl}-$ and $\mathrm{HF}$ and precipitation of s thermodynamics. (Use "V/L/S Equilibrium" model.)

\section{Mixing Tank}

Purpose: $\quad$ Mix SBW purge with sugar/carbon/other reductant

Op Range: $\quad 25-100^{\circ} \mathrm{C}$, ambient pressure

Phases: $\quad$ Aqueous (inorganic and organic), solid, gas

Phenomena: Vapor/liquid chemical equilibrium

$\mathrm{N} 2, \mathrm{NO}, \mathrm{NO} 2, \mathrm{HNO} 3, \mathrm{O} 2, \mathrm{H} 2 \mathrm{O}$ equilibrate chemically and phasically (gas/liquid). Gas phase chemical equilibration of $\mathrm{H} 2$ Temperature dependence of equilibrium limits. Potential net heat release from reactions affects temperature if heat/cooling $d$ reduction to volatile forms $(\mathrm{H} 2 \mathrm{SO} 4 / \mathrm{SO} 2 / \mathrm{SO} 3 / \mathrm{H} 2 \mathrm{~S})$.

Needed info: (1) Composition of feed to SR vessel, (2) Average concentrations of $\mathrm{H}+, \mathrm{Cl}$ - and $\mathrm{HF}$ in tank, (3) Vapor phase generation ra Species of int: N2, NO, NO2, HNO3, O2, H2O, H2, H+, Cl-, HF; CO, organic reductant; $\mathrm{H}_{2} \mathrm{SO}_{4} / \mathrm{SO}_{2} / \mathrm{SO}_{3} / \mathrm{H}_{2} \mathrm{~S}$

Related Req'ts: Feed Blending, Corrosion Allowance, Prevention of Criticality

Model descr: Blended composition of feed to next downstream component calculated as a pass through using measured concentrations of tanks. Mixing is assumed perfect. (Use "Mass Accounting" model.). Concentrations of $\mathrm{H}+, \mathrm{Cl}$ - and $\mathrm{HF}$ and vapor generatio calculated from thermodynamics. (Use "V/L/S Equilibrium" model.)

\section{Steam Reformer}

Purpose: $\quad$ Evaporate water; reduce nitrates to $\mathrm{N} 2, \mathrm{O} 2$; convert dissolved solids into a solid product suitable for packaging and disposa Op Range: $\quad 500-700^{\circ} \mathrm{C}$, ambient pressure

Phases: $\quad$ Aqueous (inorganic and organic), solid, gas

Phenomena: Finite-rate homogeneous chemical reaction, Gas phase chemical equilibrium, Interphase heat transfer with one phase dispe stream reformer offgas particulates, Steady state single-phase mixing with volumetric sources

Gas phase chemical equilibrium of $\mathrm{N} 2, \mathrm{NO}, \mathrm{NO} 2, \mathrm{HNO} 3, \mathrm{O} 2, \mathrm{H} 2, \mathrm{H} 2 \mathrm{O}, \mathrm{C}, \mathrm{CO} 2, \mathrm{CO}, \mathrm{HCs}$ (decomposition products from । Some reactions kinetically limited (e.g., oxidation of CO, HCs. Evaporation of water from droplets and coated bed material dependence of equilibrium limits. Heat release/absorption from oxidation reactions, water-gas shift reaction. Reduction of : forms $\left(\mathrm{H}_{2} \mathrm{SO}_{4} / \mathrm{SO}_{2} / \mathrm{SO}_{3} / \mathrm{H}_{2} \mathrm{~S}\right)$. Evolution of particle-laden offgas with particles formed from bed material and dissolved solic 
Table 1. (continued).

Needed info: (1) Composition, flow rate, temperature of offgas (concentrations of $\mathrm{H} 2 \mathrm{O}, \mathrm{HCl}, \mathrm{Cl} 2, \mathrm{H} 2, \mathrm{O} 2, \mathrm{NOx}, \mathrm{HCs}, \mathrm{HF}, \mathrm{CO}, \mathrm{CO} 2, \mathrm{Hg}$

$\mathrm{HgO}$ ), (2) Generation rates, compositions of fines and product solids, (3) Feed rates of additives (sugar, carbon, air, steam)

Species of int: Ionic, gaseous, nitric acid

Related Req'ts: Cl Emissions, CO Emissions, Corrosion Allowance, F Emissions, H2S Emissions, HC Emissions, Hg Emissions, Semivolati Low Volatile Metals Emissions, NOx Emissions, SOx Emissions, PM Emissions, RCRA Components of Primary Waste, R: Rad in Secondary Wastes, Rad in Process Streams, RCRA Metals in Secondary Waste, TRU in Primary Waste, TRU in Ser Volatile Rad Emissions, Nonvolatile Rad Emissions

Model descr: Gas and solid compositions, and required additive rates calculated from thermodynamic model assuming a specified reform "V/L/S Equilibrium" model. and "Mass Accounting" models.). Correct some reactions to reflect available data for species $\mathrm{m}$ (e.g., CO,) (Use "Specified Reaction" model.). Separate solids products from thermodynamic calculation into product and fi pilot scale data (Use "Specified Separation" model.).

\section{Cyclone}

Purpose: $\quad$ Gross solids separation from gas stream leaving steam reformer

Op Range: $\quad 400-700^{\circ} \mathrm{C}, 5-12$ psia

Phases: $\quad$ Solid, gas

Phenomena: Particle collection by sedimentation, Steady state heat exchange between a fluid and its boundary

Entering gas cooled by contact with device surfaces which are exposed to ambient air. Solid particles in fluid extracted acco1 diameter.

Needed info: (1) Composition and temperature of gas exiting, (2) Extraction rate and composition of solids extracted

Species of int: Solids leaving steam reformer, gas (N2, NO, NO2, O2, CO2, CO, H2, H2O)

Related Req'ts: Convert SBW to Solid, Limit HEPA Changeouts

Model descr: Assume prescribed separation of product and fines from inlet gas stream. Gas composition is a pass through. (Use "Specific "Mass Accounting" models.)

\section{Ceramic Filter}

Purpose: Collect majority of mass of particulate in off-gas directly out of steam reformer

Op Range: $\quad 300-700^{\circ} \mathrm{C}, 5-12$ psia

Phases: $\quad$ Gas, solid

Phenomena: Particle removal from gas by filtration

Larger product solid particles from reformer.

Needed info: (1) Solids loading rate on ceramic filters, (2) Composition of solids collected on ceramic filters and of fines passing througl mass loading in effluent gas, (4) Effluent gas composition

Species of int: Gas leaving steam reformer (N2, O2, Ar, CO, CO2, H2O, NOx), solids species from melter offgas

Related Req'ts: Convert SBW to Solid, Low Volatile Metals Emissions, Nonvolatile Rad Emissions, PM Emissions, Semivolatile Metals E Secondary Wastes, Limit HEPA Changeouts

Model descr: Assume specified separation of product and fines from inlet gas stream. PM compositions are pass throughs of fines and pr Fractions of fines and product particles collected based on pilot data, gas composition is a pass through. (Use "Specified Se Accounting" models.) 
Table 1. (continued).

\section{Spray Quench}

Purpose: $\quad$ Rapid cooling of gas stream with partial removal of PM

Op Range: $\quad 100-700^{\circ} \mathrm{C}, 5-12$ psia

Phases: $\quad$ Aqueous, gas, solid

Phenomena: Particle collection by sedimentation, Vapor/liquid chemical equilibrium, Interphase heat transfer with one phase disperse, $]$ entrainment in a gas stream

Some solids in influent gas extracted to liquid. Acid gas capture and dissociation (HNO3, $\mathrm{H} 2 \mathrm{SO} 4, \mathrm{HF}$, and $\mathrm{HCl}$ ). Aqueous $\mathrm{HgCl} 2, \mathrm{Hg} 2 \mathrm{Cl} 2$ ). Aqueous dissolution of soluble solids from steam reformer. Partitioning of $\mathrm{NO} 2, \mathrm{HNO} 3, \mathrm{CO} 2, \mathrm{CO}, \mathrm{Hg}, \mathrm{H}$ $\mathrm{HCl}, \mathrm{HF}, \mathrm{H} 2 \mathrm{SO} 4, \mathrm{SO} 2, \mathrm{SO} 3$ between gas and aqueous phases. Heat transport between aqueous and gas phases. Vaporizati entrainment in offgas going to downstream equipment.

Needed info: (1) Composition and temperature of gas exiting (including mass of entrained liquid), (2) Composition and temperature of li Composition of solids exiting in gas and liquid streams

Species of int: Gas (N2, NO, NO2, O2, CO2, CO, H2, Hg, H2S), near-neutral pH aqueous (NO3-, Cl-, F-, H+, H2O, SO4-2, H2SO4, solul reformer

Related Req'ts: Cl Emissions, Corrosion Allowance, Prevention of Criticality, F Emissions, Hg Emissions, Semivolatile Metals Emissions, Emissions, Volatile Rad Emissions, Nonvolatile Rad Emissions, PM Emissions, Rad in Secondary Wastes, Rad in Process Metals in Secondary Waste, SOx Emissions, TRU in Secondary Wastes, Limit HEPA Changeouts

Model descr: Separate an assumed fraction of solid particles from inlet gas stream into liquid and match to test data. (Use "Specified Ser Adiabatic thermal and chemical equilibration of gas and liquid phase based on inlet gas and liquid temperatures. Neglect $\mathrm{t}$ Liquid composition from inlet scrub composition augmented with soluble solids (and UDS) extracted from gas. Gas compo vapor/liquid equilibrium. (Use "V/L/S Equilibrium" and "Mass Accounting" models.)

\section{Submerged Bed /Packed Bed/Caustic Scrubber}

Purpose: $\quad$ Cool and/or scrub gas with liquid, solids separation

Op Range: $\quad 70-100^{\circ} \mathrm{C}, 5-12$ psia

Phases: $\quad$ Aqueous, gas, solid

Phenomena: Particle collection by sedimentation, Vapor/liquid chemical equilibrium, Two-phase flow with heat transfer, Liquid droplet stream, Finite-rate homogeneous chemical reaction

Solids loading in effluent gas. Acid dissociation ( $\mathrm{HNO} 3, \mathrm{H} 2 \mathrm{SO} 4, \mathrm{HF}$, and $\mathrm{HCl})$. Aqueous $\mathrm{Hg}$ speciation $\left(\mathrm{Hg}^{\mathrm{o}}, \mathrm{HgCl} 2, \mathrm{Hg} 2\right.$ $\mathrm{NO} 2, \mathrm{HNO} 3, \mathrm{CO} 2, \mathrm{CO}, \mathrm{Hg}, \mathrm{HgCl} 2, \mathrm{HgCl}, \mathrm{H} 2 \mathrm{O}, \mathrm{HCl}, \mathrm{HF}, \mathrm{H} 2 \mathrm{SO} 4, \mathrm{SO} 2, \mathrm{SO} 3$ between gas and aqueous phases. Heat transf $\&$ gas phases. Vaporization/condensation of water. Droplet concentration in offgas going to downstream equipment.

Needed info: (1) Composition and temperature of gas exiting (including mass of entrained liquid), (2) Composition and temperature of li Composition of solids exiting in gas and liquid streams

Species of int: Effluent gas from upstream scrubber (could contain N2, NO, NO2, O2, CO2, CO, H2, H2O, HCs, Cl2, SO2, SO3, HF, HC] aqueous (Na+, NO3-, Cl-, F-, OH-, CO3-2, HCO3-, H2O, SO3-2, SO4-2, HgCl2, HgCl, Hg+2, cations from dissolved solid

Related Req'ts: Cl Emissions, Corrosion Allowance, Prevention of Criticality, F Emissions, Hg Emissions, Semivolatile Metals Emissions, Emissions, Volatile Rad Emissions, Nonvolatile Rad Emissions, PM Emissions, Rad in Secondary Wastes, Rad in Process Metals in Secondary Waste, SOx Emissions, TRU in Secondary Wastes, Limit HEPA Changeouts

Model descr: Separate an assumed fraction of solid particles from inlet gas stream into liquid and match to test data. (Use "Specified Ser Adiabatic thermal and chemical equilibration of gas and liquid phase based on inlet gas and liquid temperatures. Neglect tl Liquid composition from inlet scrub composition augmented with soluble solids (and UDS) extracted from gas. Gas compo vapor/liquid equilibrium. (Use "V/L/S Equilibrium" and "Mass Accounting" models.) 
Table 1. (continued).

\section{HEME (high efficiency mist eliminator, demister)}

Purpose: $\quad$ Collect liquid scrub droplets remaining in offgas prior to final HEPA filtration and Hg removal in GAC columns. Collect st particles from offgas.

Op Range: $\quad 50-175^{\circ} \mathrm{C}, 5-12$ psia

Phases: $\quad$ Gas, liquid

Phenomena: Vapor/liquid chemical equilibrium, Mist removal

Acid dissociation (HNO3, $\mathrm{H} 2 \mathrm{SO} 4, \mathrm{HF}$, and $\mathrm{HCl}$ ). Aqueous $\mathrm{Hg}$ speciation ( $\mathrm{Hgo}, \mathrm{HgCl} 2, \mathrm{HgCl}$ ). Partitioning of $\mathrm{NO} 2, \mathrm{HNO} 3$ $\mathrm{HgCl} 2, \mathrm{HgCl}, \mathrm{H} 2 \mathrm{O}, \mathrm{HCl}, \mathrm{HF}, \mathrm{H} 2 \mathrm{SO} 4, \mathrm{SO} 2, \mathrm{SO} 3$ between gas and aqueous phases. Vaporization/condensation of water

Needed info: (1) Composition of gas exiting (including entrained liquid and solids), (2) Composition of liquid exiting, (3) Composition of and liquid streams

Species of int: Effluent gas from upstream scrubber, scrub liquid from upstream scrubber

Related Req'ts: Cl Emissions, Corrosion Allowance, Prevention of Criticality, F Emissions, Hg Emissions, TRU in Secondary Wastes, Lim

Model descr: Assume separation factors for key solid species of interest and entrained liquid and adjust to agree with pilot data. Compos product solid particles are pass throughs (Use "Mass Accounting" model.). Concentrations of acid gases (HF, Cl-, SOx) and (elemental $\mathrm{Hg}$ in separate liquid phase) calculated from thermodynamics. Composition of liquid from pass through of enter] by dissolution of soluble solids and acid gases extracted from offgas. (Use "V/L/S Equilibrium" model.)

\section{Scrub Collection Tank}

Purpose: Accumulate scrub solution for recirculation through scrubbers, quenchers, etc. Equilibrate $\mathrm{pH}$ in entering streams and prov scrubber blowdown liquid for downstream treatment processes.

Op Range: $\quad 10-33^{\circ} \mathrm{C}$, ambient pressure

Phases: $\quad$ Aqueous, gas

Phenomena: Gas/liquid/solid equilibrium,

Salts associated with combinations of ions from the major \& minor species lists above. Soluble complexes of F-, $\mathrm{Cl}$ -

Species of int: Liquids from primary and secondary (caustic) scrubbing operations ( $\mathrm{H}+, \mathrm{OH}-, \mathrm{H} 2 \mathrm{CO} 3, \mathrm{HCO} 3-)$, vent gas $(\mathrm{CO} 2, \mathrm{H} 2 \mathrm{O}, \mathrm{N} 2,1$ from entering liquid streams and precipitates from chemical equilibration)

Needed info: (1) Composition (including radionuclides, $\mathrm{H}+, \mathrm{OH}-$, carbonates) and temperature of scrub liquor fed to scrubbers, quencher UDS, TDS concentrations in scrub liquor, (3) Compositions of solids in liquid streams drawn from the tank.

Related Req'ts: Corrosion Allowance, Prevention of Criticality,RCRA Metals in Secondary Waste, TCLP for Secondary Waste, TRU in Sec

Model descr: Thermodynamic chemical and phase equilibration of entering liquid streams. (Use "V/L/S Equilibrium" and "Mass Accoun

\section{Solid/Liquid Separator}

Purpose: $\quad$ Separate high-rad solids from quench purge solution that is to be treated and disposed as LLW

Op Range: $\quad 20-100^{\circ} \mathrm{C}, 5-12$ psia

Phases: $\quad$ Liquid, solid

Phenomena: Liquid, Particle collection by sedimentation, Particle impingement due to inertia

Needed info: (1) Solids composition, (2) Liquid composition and solids concentration

Species of int: Liquid (scrub liquor--Na+, $\mathrm{K}+, \mathrm{Al}+3, \mathrm{OH}, \mathrm{Na} 2 \mathrm{CO} 3$, water, $\mathrm{NO} 3-, \mathrm{HCl}, \mathrm{H} 2 \mathrm{SO} 3, \mathrm{H} 2 \mathrm{SO} 4, \mathrm{HF}, \mathrm{H}+, \mathrm{OH}-$ ), solids in scrub liq reformer

Related Req'ts: Liquids in Wastes, Rad in Secondary Wastes, Rad in Process Streams, TRU in Secondary Wastes, Waste Form Disposabili

Model descr: Assume specified separation of solids from inlet liquid stream. Solid and liquid compositions are pass throughs of liquid as stream. (Use "Specified Separation" and "Mass Accounting" models.). 
Table 1. (continued).

\begin{tabular}{ll}
\hline 11. Acid Fractionator (distillation column) \\
$\begin{array}{ll}\text { Purpose: } & \text { Recover } \mathrm{HNO} 3 \text { from evaporator overheads } \\
\text { Op Range: } & 90--115^{\circ} \mathrm{C}, 10-12 \mathrm{psia} \\
\text { Phases: } & \text { Gas, liquid } \\
\text { Phenomena: } & \text { Vapor/liquid chemical equilibrium } \\
\text { Needed info: } & \text { (1) Gas composition after extraction of HNO3 and other acid gases, (2) Fractionator liquid effluent composition } \\
\text { Species of int: } & \mathrm{HNO} 3, \mathrm{HCl}, \mathrm{HF}, \mathrm{H} 2 \mathrm{O}, \mathrm{Hg}, \mathrm{HgCl} 2, \mathrm{H} 2 \mathrm{SO} 4, \mathrm{SO} 2, \mathrm{SO} 3 \\
\text { Related Req'ts: } & \mathrm{Cl} \text { Emissions, Corrosion Allowance, F Emissions, H2S Emissions, Hg Emissions, NOx Emissions, SOx Emissions } \\
\text { Model descr: } & \text { Concentrations of HNO3, NOx, Cl-, sulfur species, and HF in gas and liquid phases calculated from thermodynamics. Othe } \\
& \text { throughs (Use "V/L/S Equilibrium" and "Mass Accounting" models.). }\end{array}$ \\
\hline
\end{tabular}

\section{Condenser}

Purpose: $\quad$ Reduce offgas temperature to extract condensable species (primarily $\mathrm{H} 2 \mathrm{Oand} / \mathrm{or} \mathrm{Hg}$ ) to liquid phase for recycle, storage or Reduce gas volume

Op Range: $\quad 15-100^{\circ} \mathrm{C}, 5-12$ psia

Phases: $\quad$ Gas, liquid

Phenomena: Vapor/liquid chemical equilibrium, Steady state heat exchange between a fluid and its boundary, Steady state heat exchang in a heat exchanger

Needed info: (1) Gas exit composition, flow rate, and temperature, (2) Condensate composition, flow rate, and temperature, (3) cooling 1 temperature of coolant

Species of int: Gas (H2O), liquid (H2O)

Related Req'ts: Corrosion Allowance, Limit HEPA Changeouts

Model descr: Condensation of water vapor and associated cooling duty calculated from thermodynamics. (Use "V/L/S Equilibrium" and ' models.)

\section{Evaporator/Salt Dryer}

Purpose: $\quad$ Remove part or all $\mathrm{H} 2 \mathrm{O}$ from SBW feed or scrubber blowdown by evaporation to gas phase.

Op Range: $\quad 25-150^{\circ} \mathrm{C}, 10-12$ psia

Phases: $\quad$ Aqueous, gas, solid

Phenomena: Gas/liquid/solid equilibrium, Two-phase flow with heat transfer, Steady state heat exchange between two fluids in a heat e Evaporation of water from evaporator feed. Partitioning of $\mathrm{NO} 2, \mathrm{CO} 2, \mathrm{Hg}, \mathrm{HNO} 3, \mathrm{HCl}, \mathrm{HF}, \mathrm{H} 2 \mathrm{O}, \mathrm{H} 2 \mathrm{SO} 4, \mathrm{Hg}, \mathrm{HgCl} 2, \mathrm{H}$ between evaporator bottoms and overheads. Precipitation of nitrate, sulfate, chloride, fluoride, phosphate salts. Scaling depo [Schindler (1998)]. Soluble complexes of F- and Cl- with $\mathrm{Al}+3, \mathrm{Cr}+3, \mathrm{Fe}+3, \mathrm{Zr}+4, \mathrm{H} 2 \mathrm{BO} 3$.

Needed info: (1) Gas (overheads) exit composition, flow rate, and temperature, (2) Bottoms (liquid or solid) exit composition, flow rate, Presence or absence of solid precipitates (including scaling deposits), (4) Composition of solids leaving with bottoms.

Species of int: Gas (N2, O2, CO2, CO, H2, Hg, HgCl2, HCl, H2SO4, HF, NOx), aqueous (Cl-, F-, H+, H2O, SO4-2, Hg ${ }^{\circ}, \mathrm{Hg}+2, \mathrm{HgCl} 2, \mathrm{c}$; solids in feed), solid (UDS in feed, scaling deposits[CaCO3, $\mathrm{SiO} 2]$, precipitates formed by over concentration of the feed)

Related Req'ts: Cl Emissions, F Emissions, $\mathrm{Hg}$ Emissions, Corrosion Allowance, Prevention of Criticality

Model descr: Evaporation of water vapor and associated heating duty as well as precipitation of solids from phasic and chemical equilibriu is a pass through. (Use "V/L/S Equilibrium" and "Mass Accounting" models.) 
Table 1. (continued).

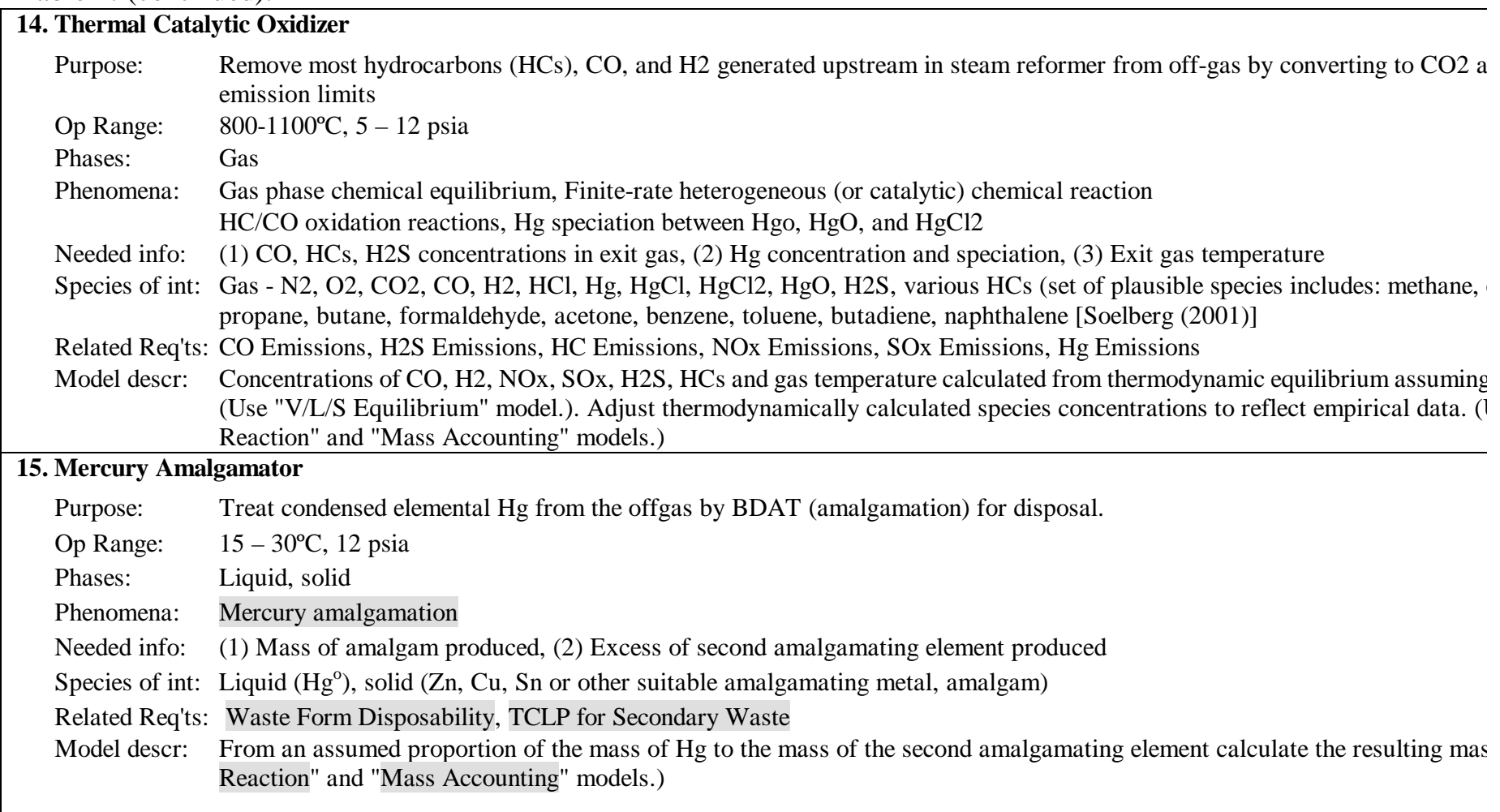

\section{Mercury Removal by GAC Adsorption}

Purpose: $\quad$ Remove $\mathrm{Hg} \&$ organics

Op Range: $\quad 100-200^{\circ} \mathrm{C}, \approx 5$ psia (subatmospheric)

Phases: $\quad$ Gas, solid

Phenomena: Adsorption

Adsorption of $\mathrm{Hg}^{\mathrm{o}}, \mathrm{HgCl} 2, \mathrm{I}-129$, and organics from the offgas prior to stack release

Needed info: (1) Concentrations of $\mathrm{Hg}$, I-129, and organic species in offgas, (2) Consumption rate of GAC

Species of int: $\mathrm{Hg}$ species, iodine, trace organics, other gas species

Related Req'ts: Waste Form DisposabilityWaste Form DisposabilityWaste Form Disposability Hg Emissions, HC Emissions, Volatile Rad

Model descr: Assume a loading ratio (mass GAC/total mass adsorbed) and apply this to a stoichiometric reaction between $\mathrm{Hg}$, I, and $\mathrm{HC}$ : produces spent (i.e., fully-loaded) GAC as a product. Adjust the loading ratio as necessary to reflect empirical data, and to : competing reactions for GAC adsorption sites as indicated by test data. (Use "Mass Accounting" and "Specified Reaction" 1 
Table 1. (continued).

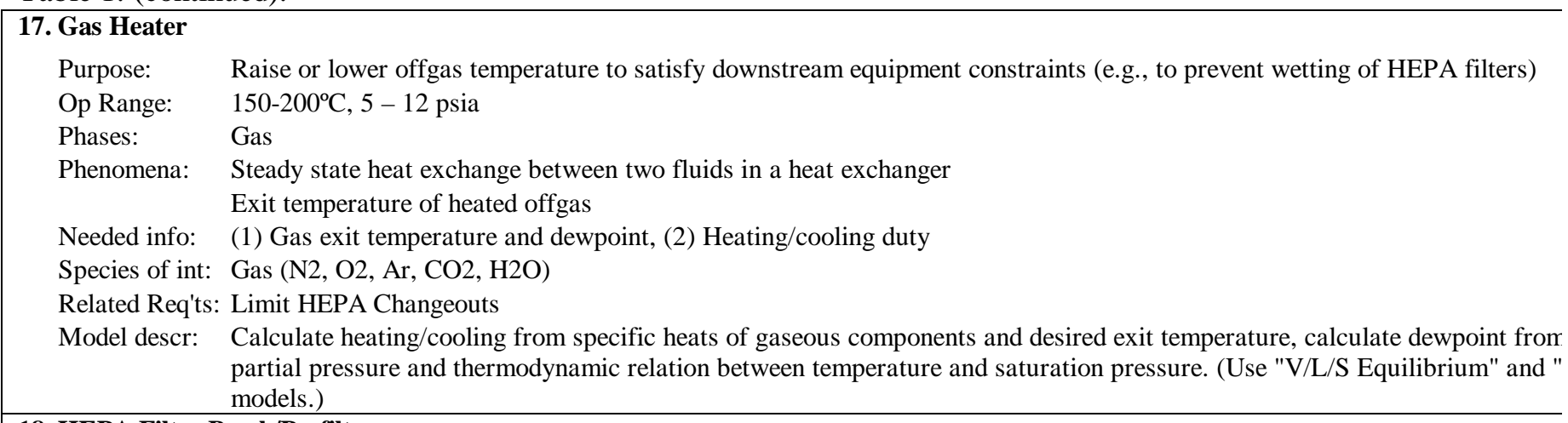

\section{HEPA Filter Ba nk/Prefilter}

Purpose: $\quad$ Collect all particulate remaining in off-gas prior to discharge to the atmosphere

Op Range: $\quad 20-100^{\circ} \mathrm{C}, 5-12$ psia

Phases: Gas, solid

Phenomena: Particle removal from gas by filtration

Needed info: (1) Concentrations of PM, semivolatile metals, low volatile metals, nonvolatile rad, volatile rad, $\mathrm{Hg}, \mathrm{Cl}, \mathrm{HCs}, \mathrm{CO}$, dioxins/f Mass loading rate of HEPA filters, (3) Rad concentration in loaded HEPA filters

Species of int: Gas (N2, O2, Ar, CO2, H2O, NOx), solids species from melter offgas

Related Req'ts: Low Volatile Metals Emissions, Semivolatile Metals Emissions, Volatile Rad Emissions, Nonvolatile Rad Emissions, PM Secondary Wastes, Rad in Process Streams, TRU in Secondary Wastes

Model descr: Filters assumed to remove only particulates and specified separation factors used to determine quantity of PM removed from particulate compositions. Concentrations of gaseous species are pass throughs. (Use "Specified Separation" and "Mass Acc

\section{BFW Treatment and Steam Generator}

Purpose: $\quad$ Generate steam for steam reformer from recovered water

Op Range: $\quad 60-100^{\circ} \mathrm{C}, 12-15$ psia

Phases: $\quad$ Gas, liquid

Phenomena: Adsorption, Degassing of Liquid

Removal of alkalinity by ion exchange; mechanical degasification

Needed info: (1) Concentrations of TDS, PO4-3, CO3-2, HCO3-, OH-, SO3-2, SiO2, (2) Total Fe and SiO2 in recovered condensate, (3) sorbents

Species of int: Dissolved gases (CO2, O2) dissolved salts (PO4-3, CO3-2, SO3-2, Fe+3) solids (SiO2), organics

Related Req'ts: Corrosion Allowance

Model descr: Filters assumed to remove only particulates and specified separation factors used to determine quantity of PM removed fron particulate compositions. Concentrations of gaseous species are pass throughs. (Use "Specified Separation" and "Mass Acc

Note: Unit operation 10 may be excluded if the is not a significant difference in the activity levels of the scrub blowdown liqui 
Table 2. Process requirements.

\begin{tabular}{|c|c|}
\hline REQUIREMENT NAME & DESCRIPTION \\
\hline Feed Blending & Feeds to a unit operation must be blended and homogenized, maintaining all solids in suspension that are in \\
\hline Convert SBW to Solid & Radioactive components of liquid SBW from the TFF must be converted into a solid form suitable for direct \\
\hline Corrosion Allowance & Materials of construction must accommodate expected corrosion rates. \\
\hline Prevention of Criticality & Criticality limits on aggregations of fissionable species must not be exceeded. \\
\hline NOx Emissions & $\begin{array}{l}\text { NOx emissions above } 40 \mathrm{~T} / \mathrm{yr} \text { are considered "significant" by the state and subject to regulation. Since nitrat } \\
\text { produce about } 1,300 \mathrm{~T} \text { of NOx it is expected that a NOx concentration limit would be imposed on stack emi }\end{array}$ \\
\hline SOx Emissions & $\begin{array}{l}\mathrm{SO}_{2} \text { emissions above } 40 \mathrm{~T} / \mathrm{yr} \text { are considered "significant" by the state and subject to regulation. Since the tot } \\
\text { produce about } 14 \mathrm{~T} \text { of } \mathrm{SO}_{2} \text { it is assumed unlikely that any limit on } \mathrm{SO}_{2} \text { emissions would be imposed. }\end{array}$ \\
\hline H2S Emissions & $\begin{array}{l}\mathrm{H}_{2} \mathrm{~S} \text { emissions above } 10 \mathrm{~T} / \mathrm{yr} \text { are considered "significant" by the state and subject to regulation. Since the tot } \\
\text { produce about } 7.1 \mathrm{~T} \text { of } \mathrm{H}_{2} \mathrm{~S} \text { it is assumed unlikely that any limit on } \mathrm{H}_{2} \mathrm{~S} \text { emissions would be imposed. }\end{array}$ \\
\hline Cl Emissions & $\mathrm{HCl}$ and $\mathrm{Cl}_{2}$ are regulated by MACT. The total $\mathrm{Cl}$ concentration must be less than $75 \mathrm{ppmv}$ \\
\hline F Emissions & $\begin{array}{l}\text { Fluoride }(\mathrm{F}) \text { in SBW could be released in the offgas. F emissions exceeding } 3 \mathrm{~T} / \mathrm{yr} \text { is considered "significant } \\
\text { regulation. Since SBW has more than } 6 \mathrm{~T} \text { of fluoride, fluoride in stack gas would likely be regulated below : }\end{array}$ \\
\hline Hg Emissions & $\mathrm{Hg}$ in stack off-gas is regulated by MACT. The total $\mathrm{Hg}$ concentration must be less than $40 \mu \mathrm{g} / \mathrm{dsm}^{3}$. \\
\hline Volatile Rad Emissions & Volatile radionuclide emissions in stack off-gas are regulated by NESHAPs to specific limits. \\
\hline Nonvolatile Rad Emissions & Non-volatile radionuclide emissions in stack off-gas are regulated by NESHAPs to specific limits. \\
\hline Semivolatile Metals Emissions & $\mathrm{Pb}$ and $\mathrm{Cd}$ are considered semivolatile metals and are regulated by MACT to below $100 \mu \mathrm{g} / \mathrm{dm}^{3}$. \\
\hline Low Volatile Metals Emissions & $\mathrm{Sb}, \mathrm{As}, \mathrm{Cr}$, and $\mathrm{Be}$ are considered low-volatility metals and are regulated by MACT to below $55 \mu \mathrm{g} / \mathrm{dsm}^{3}$. \\
\hline CO Emissions & $\mathrm{CO}$ is regulated by MACT to less than $100 \mathrm{ppmv.}$ \\
\hline HC Emissions & Total hydrocarbons (HCs) is regulated by MACT to less than $10 \mathrm{ppmv.}$ \\
\hline PM Emissions & Particulate matter (PM) is regulated by MACT to less than $0.015 \mathrm{gr} / \mathrm{dsm}^{3}$. \\
\hline TCLP for Secondary Waste & RCRA metals in secondary waste must satisfy TCLP leaching limits. \\
\hline $\begin{array}{l}\text { RCRA Metals in Secondary } \\
\text { Waste }\end{array}$ & Concentrations of RCRA metals in secondary wastes disposed at Hanford must satisfy limits imposed by the \\
\hline Rad in Secondary Wastes & $\begin{array}{l}\text { Concentrations of radionuclides in secondary wastes disposed at LLW or LLMW disposal sites must be belov } \\
\text { category) of waste disposal. }\end{array}$ \\
\hline TRU in Primary Waste & $\begin{array}{l}\text { Concentrations of TRU radionuclides in wastes disposed at WIPP must be at least } 100 \mathrm{nCi} / \mathrm{gm} \text { and in wastes } \\
\text { must be at most } 10 \mathrm{nCi} / \mathrm{gm} \text {. }\end{array}$ \\
\hline TRU in Secondary Wastes & $\begin{array}{l}\text { Concentrations of TRU radionuclides in wastes disposed at WIPP must be at least } 100 \mathrm{nCi} / \mathrm{gm} \text { and in wastes } \\
\text { must be at most } 10 \mathrm{nCi} / \mathrm{gm} \text {. }\end{array}$ \\
\hline Liquids in Wastes & Water must be removed from all waste streams (SBW liquid, tank and heel solids, NGLW), preparatory to $\mathrm{p}$ \\
\hline $\begin{array}{l}\text { RCRA Components of Primary } \\
\text { Waste }\end{array}$ & Identities and maximum potential concentrations of RCRA components in the primary waste product must $b$ \\
\hline Rad in Primary Waste & Identities and maximum potential concentrations of radionuclides in the primary waste product must be dete \\
\hline Rad in Process Streams & Identities and maximum potential concentrations of radionuclides in the process streams must be determines \\
\hline
\end{tabular}


Table 2. (continued).

\begin{tabular}{|l|l}
\hline REQUIREMENT NAME & DESCRIPTION \\
\hline Limit HEPA Changeouts & $\begin{array}{l}\text { Spent HEPA filters constitute an additional waste stream that must be treated and disposed. Changeout of H } \\
\text { burden. Both considerations dictate that the sole function of HEPA filters should be to polish the final offgas } \\
\text { be used as a primary particulate removal device. Thus, the bulk of offgas fine particulates must be removed } \\
\text { system, and moisture in the offgas entering the HEPA banks must be prevented from condensing and wettin }\end{array}$ \\
\hline Waste Form Disposability & All waste streams from the process must be converted to waste forms which satisfy the acceptance criteria a
\end{tabular}


Table 3. Phenomena in unit operations.

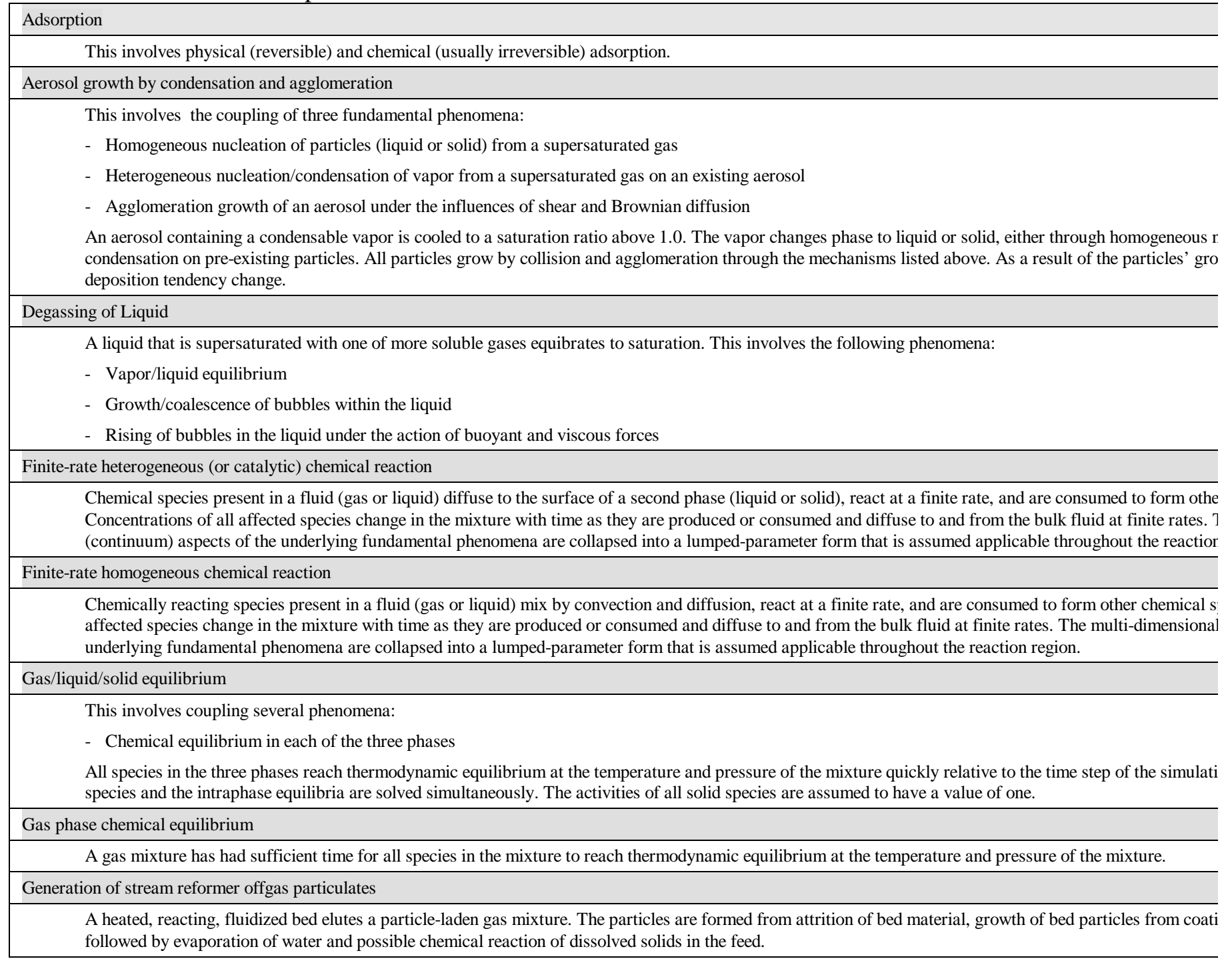


Table 3. (continued).

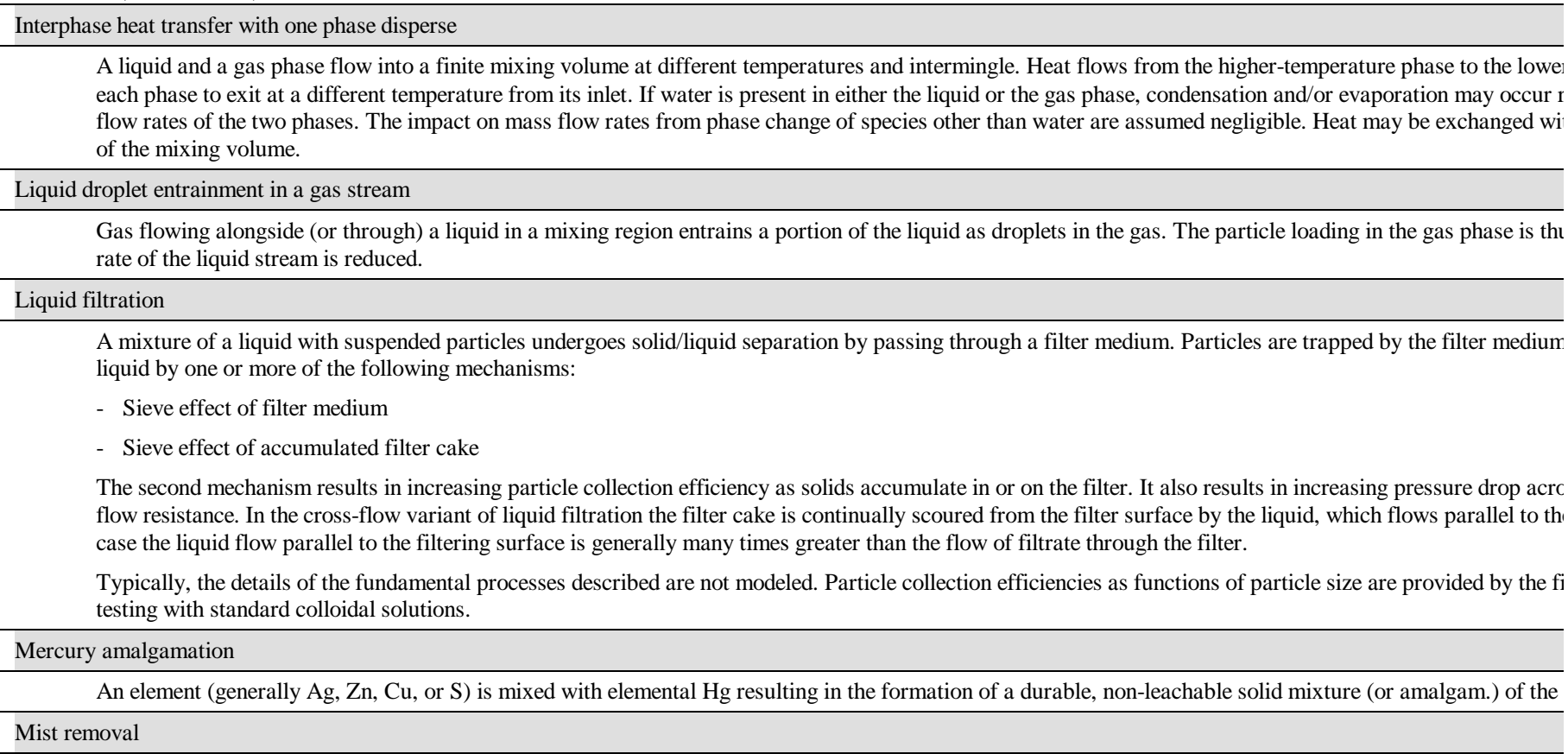

A gas laden with liquid droplets forced to flow tangentially into a cylindrical vessel and then parallel to the cylindrical axis through a fine mesh structure (usu: or an inert material such as fiberglass, Kevlar, etc.). Larger liquid droplets impinge on the cylindrical wall due to centrifugal force. Smaller droplets follow the structure where most are collected by one or more of the following mechanisms:

- Sieve effect

- Brownian diffusion within gas phase to liquid boundary

The second mechanism occurs by virtue of the mesh structure being coated with a layer of liquid. The gas bubbles through the liquid layer after being disperse through the mesh. As the gas bubbles pass through the liquid layer the finest particles can diffuse to the spherical surfaces of the bubbles and be collected by th being below what would be collected by the sieve effect.

Typically, the details of the fundamental processes described may not all be modeled. Overall particle collection efficiencies may typically be provided by HEl of particle size, mesh fineness, and gas/liquid and flow ratio.

Particle collection by sedimentation

Solid particles suspended in a fluid (gas or liquid) migrate through the fluid under the action of a body force (e.g., gravity, centrifugal force, etc.) in a collectin packed bed scrubber tank, cyclone, centrifuge, etc.) onto a collecting surface. (In a packed bed gas scrubber the surface would be the liquid on the surface of tl particle concentration in the fluid decreases as the fluid passes through the collecting device.

Particle impingement due to inertia

Particles (solid or liquid) in a flowing fluid move under the influence of the fluid viscous force and inertia of the particles themselves. When the flow path of th particle trajectories may result in impingement on a flowfield boundary. Extraction of the particles from the fluid and material deposition on the boundary rest 
Table 3. (continued).

\begin{tabular}{l} 
Particle removal from gas by filtration \\
\hline This involves the coupling of three fundamental phenomena: \\
- Viscous single-phase flow with volumetric sources \\
- Brownian diffusion of particles from bulk gas to a sink \\
- Particulate removal by sieve action \\
A gas containing an aerosol is forced through a fibrous medium. Particles in the gas move with the gas by advection and within the gas by Brownian diffusion. \\
medium is assumed to be a sink for particles (i.e., zero particle concentration in the gas exists at the surface) and the particles diffuse toward the medium by vi \\
gradient. As the gas move through the medium the concentration of particles is depleted according to the total residence time and diffusion behavior of the gas. \\
Typically, the details of the fundamental processes above are not all modeled. Overall particle collection efficiencies are typically provided by filter medium vı \\
size (and sometimes pressure drop through the fiber).
\end{tabular}
Solid/liquid chemical equilibrium

In a liquid mixture all species present in the liquid phase react to form compounds as a result of a specified set of reactions. In addition, electrolytes dissociate species. The species within the liquid phase reach thermodynamic chemical equilibrium at the temperature and pressure of the mixture (this assumes that suffi equilibration of all reactions). Species in the liquid phase will (in general) include ionic and molecular species in solution as well as soluble complexes.

Dissolved species in the liquid remain in solution if it is thermodynamically favorable to do so. Otherwise, separate solid phases precipitate, each composed of forms of the corresponding species (molecular or ionic) in solution. Such precipitation continues until the species in the solid and liquid phases reach thermods temperature and pressure of the mixture.

The phasic and chemical equilibrium are perfectly coupled. If some species precipitate from solution, the change to their concentrations in solution is instantly of the liquid mixture.

This involves the coupling of two fundamental phenomena:

- Viscous single-phase flow with volumetric sources

- Heat transfer at a fluid boundary

A moving fluid at one temperature flows next to a solid boundary at a different temperature. Heat flows between the fluid and the boundary by two paths: (a) bulk fluid and the boundary, and (b) via conduction between the viscous sublayer and the boundary. The fluid temperature in the sublayer is determined by he to the region near the boundary. This intrafluid transport is driven by velocity and thermal gradients. The boundary is assumed to have sufficiently high therm: can be treated as an infinite sink at constant temperature.

Typically, the details of the fundamental processes above are not all modeled. Macroscopic models have been developed which correlate the heat transfer rate with macroscopic parameters (e.g., Re, Pr, etc.)

Steady state heat exchange between two fluids in a heat exchanger

This involves the coupling of three fundamental phenomena:

- Viscous single-phase flow with volumetric sources

- Heat transfer at a fluid boundary

- Conduction heat transfer through a solid wall

Two moving fluids at two different temperatures flow through passageways which are separated by a solid boundary. By virtue of the temperature gradient be the warmer to the colder through the solid wall which separates them. Heat flows between the bulk fluids and the wall via radiation and at the wall/fluid interf and thermal gradients within the fluids are established and heat is transported from the bulk fluids to the viscous sublayers next to the wall by conduction and

Typically, the details of the fundamental processes above are not all modeled. Macroscopic models have been developed which correlate the heat transfer rate macroscopic flow parameters (e.g., Re, Pr, etc.) 
Table 3. (continued).

Steady state single-phase mixing with volumetric sources

Chemical species present in one or more homogeneous streams flow into a mixing volume and mix before leaving in a single, blended stream. Mixing occurs a at finite rates. Chemical species diffuse through the mixture and are produced or consumed by volumetric sources (e.g., chemical reactions). The composition , spatially and temporally according to the mixing and volumetric sources within the mixing volume.

Two-phase flow with heat transfer

Liquid flow and vapor flow in the same space and undergo phase change with water the principal specie moving between the phases. Heat transfer between the gas may influence the evaporation or condensation of water. The dynamics of the flow (e.g., the effective friction factor and pressure drop in pipe flow, the effi heat transfer coefficients, etc.) are influenced by the presence of the second phase and by the phase changes.

Vapor/liquid equilibrium

In a liquid and gas mixture all species present reach a state of thermodynamic equilibrium between its gaseous and liquid forms is also achieved for each speci gaseous forms (this assumes that sufficient time is provided for full equilibration of all species between the liquid and gas phases).

Vapor/liquid chemical equilibrium

In a liquid/gas mixture all species present react to form a specified set of compounds as a result of a specified set of reactions. In addition, electrolytes dissocia and some species in the liquid phase will also form soluble complexes. The species within the liquid and gas phases reach thermodynamic equilibrium at the te mixture (this assumes that sufficient time is provided for full equilibration of all reactions). Equilibrium is simultaneously achieved for each specie between its (in the case of an electrolyte) between its molecular and dissociated forms. Effects of phase changes for each specie on concentrations in the liquid and gas pha intraphase chemical equilibrations.

Waste form properties as functions of processing parameters

A waste feed is transformed into a waste form (e.g., glass, grout, etc.) by a process (e.g., a glass melter, a grout mixing/casting/curing operation, etc.). The prol leaching rate of hazardous constituents, liquidus temperature, phases present, compressive strength, etc.) are completely determined by (a) the composition of 1 parameters. Because of this determinism the quantitative measures of the waste form properties can be predicted by some function of the composition variables (e.g., through multivariate linear regression of measured data, through thermodynamic equations, etc.). 
Table 4. Process simulator modeling capabilities.

\begin{tabular}{|l|l|l}
\hline \multicolumn{1}{|c|}{ CAPABILITY } & \multicolumn{1}{|c}{$\begin{array}{c}\text { MODELING } \\
\text { METHOD }\end{array}$} & DESCRIPTION \\
\hline Mass Accounting & N/A & $\begin{array}{l}\text { Elemental species present in input streams are tracked through the process such that for each } \\
\text { rate (in all input streams) is accounted for in its total output mass flow rate (in all output strt } \\
\text { each element among all output streams, chemical compounds, and phases is tracked. }\end{array}$ \\
\hline V/L/S Equilibrium & Mechanistic & $\begin{array}{l}\text { Within a component user-specified chemical species are formed from user-specified element } \\
\text { between phases (V-vapor, L-liquid, S-solid) assumed to be present so as to achieve thermod } \\
\text { and between the phases. All other specie present in the component's input streams are treate }\end{array}$ \\
\hline Specified Reaction & Empirical & $\begin{array}{l}\text { Designated chemical species present within a component, specified by the user, react accord } \\
\text { stoichiometric coefficients and reaction extents are specified by the user. }\end{array}$ \\
\hline Specified Separation & Empirical & $\begin{array}{l}\text { Designated species, phases, streams, etc. present in the input streams to a component are dir } \\
\text { streams according to a user-supplied specification. }\end{array}$ \\
\hline
\end{tabular}


Table 5. Representative compositions of SBW (a) dilute SBW feed. ${ }^{a}$

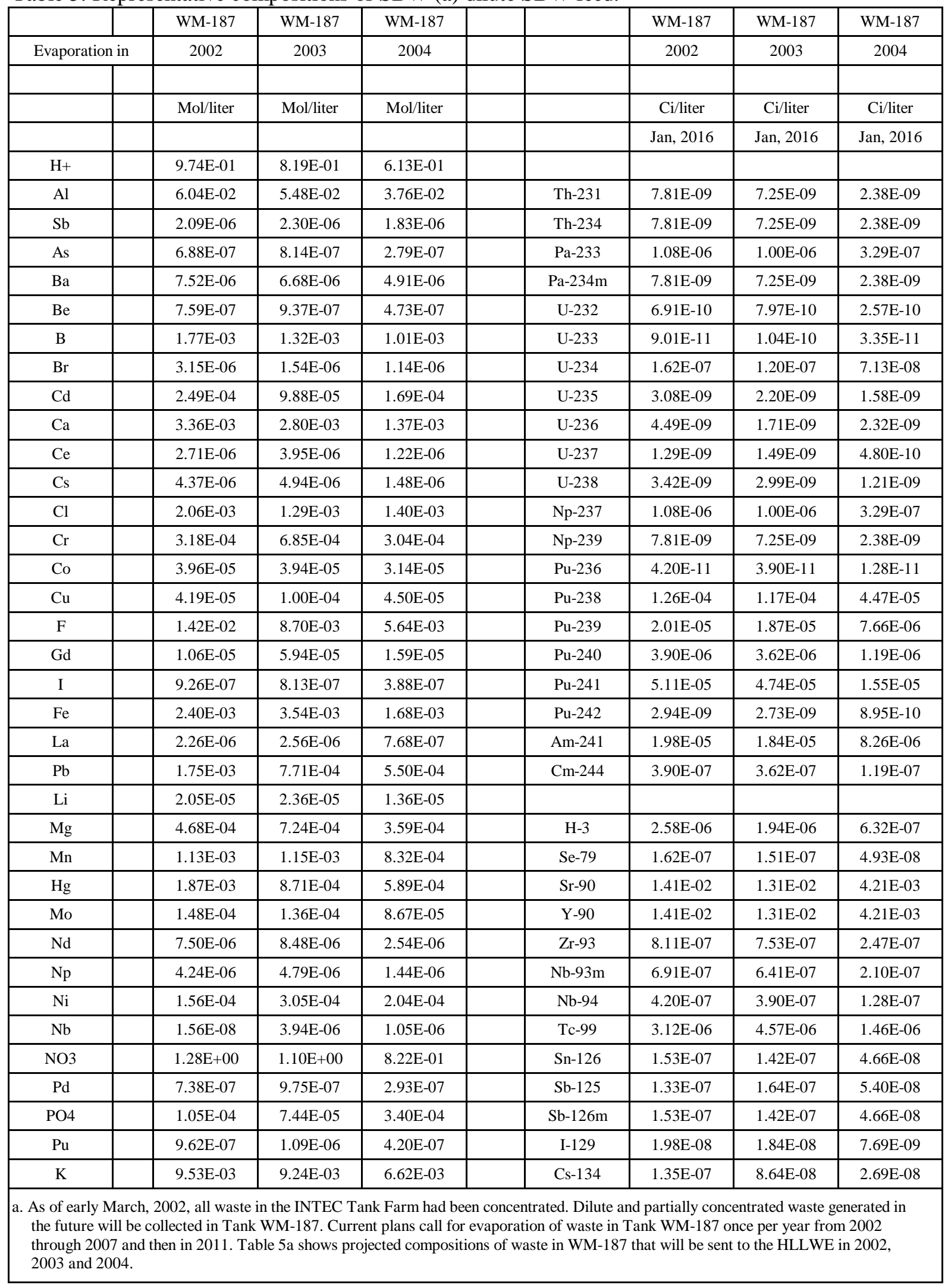


Table 5(a). (continued).

\begin{tabular}{|c|c|c|c|c|c|c|c|}
\hline & WM-187 & WM-187 & WM-187 & & WM-187 & WM-187 & WM-187 \\
\hline Evaporation in & 2002 & 2003 & 2004 & & 2002 & 2003 & 2004 \\
\hline & Mol/liter & Mol/liter & Mol/liter & & $\mathrm{Ci} / \mathrm{liter}$ & $\mathrm{Ci} /$ liter & $\mathrm{Ci} / \mathrm{liter}$ \\
\hline & & & & & Jan, 2016 & Jan, 2016 & Jan, 2016 \\
\hline $\operatorname{Pr}$ & 2.09E-06 & 2.37E-06 & $7.09 \mathrm{E}-07$ & Cs-135 & $3.30 \mathrm{E}-07$ & $3.07 \mathrm{E}-07$ & $1.01 \mathrm{E}-07$ \\
\hline $\mathrm{Rh}$ & $9.17 \mathrm{E}-07$ & $1.04 \mathrm{E}-06$ & $3.11 \mathrm{E}-07$ & Cs-137 & $1.38 \mathrm{E}-02$ & $1.28 \mathrm{E}-02$ & $4.20 \mathrm{E}-03$ \\
\hline $\mathrm{Rb}$ & 2.04E-06 & $2.31 \mathrm{E}-06$ & $6.83 \mathrm{E}-07$ & Ba-137m & $1.30 \mathrm{E}-02$ & $1.21 \mathrm{E}-02$ & $3.96 \mathrm{E}-03$ \\
\hline $\mathrm{Ru}$ & 4.77E-06 & $9.58 \mathrm{E}-06$ & 2.72E-06 & Pm-146 & $3.60 \mathrm{E}-09$ & $3.35 \mathrm{E}-09$ & $1.10 \mathrm{E}-09$ \\
\hline $\mathrm{Sm}$ & $1.44 \mathrm{E}-06$ & $1.63 \mathrm{E}-06$ & 4.88E-07 & Pm-147 & $2.04 \mathrm{E}-06$ & $1.90 \mathrm{E}-06$ & $6.21 \mathrm{E}-07$ \\
\hline $\mathrm{Si}$ & $2.25 \mathrm{E}-04$ & $3.09 \mathrm{E}-04$ & $1.58 \mathrm{E}-04$ & Sm-151 & $1.14 \mathrm{E}-04$ & $1.06 \mathrm{E}-04$ & $3.47 \mathrm{E}-05$ \\
\hline $\mathrm{Na}$ & $9.22 \mathrm{E}-02$ & 8.19E-02 & 7.73E-02 & Eu-152 & $4.81 \mathrm{E}-07$ & $4.46 \mathrm{E}-07$ & $1.46 \mathrm{E}-07$ \\
\hline $\mathrm{Sr}$ & 4.11E-06 & $7.45 \mathrm{E}-06$ & 2.18E-06 & Eu-154 & $1.70 \mathrm{E}-05$ & $1.69 \mathrm{E}-05$ & $5.33 \mathrm{E}-06$ \\
\hline $\mathrm{SO} 4$ & $2.85 \mathrm{E}-03$ & 2.92E-03 & $2.08 \mathrm{E}-03$ & $\mathrm{Eu}-155$ & 4.03E-06 & $2.16 \mathrm{E}-06$ & $9.14 \mathrm{E}-07$ \\
\hline $\mathrm{Ti}$ & 3.09E-06 & 4.35E-06 & $2.20 \mathrm{E}-06$ & Co-60 & $9.46 \mathrm{E}-07$ & $8.11 \mathrm{E}-07$ & 3.37E-07 \\
\hline $\mathrm{U}$ & 2.73E-05 & $3.60 \mathrm{E}-05$ & $1.76 \mathrm{E}-05$ & $\mathrm{Ni}-63$ & $1.05 \mathrm{E}-05$ & $9.76 \mathrm{E}-06$ & $3.20 \mathrm{E}-06$ \\
\hline V & $2.25 \mathrm{E}-05$ & $6.44 \mathrm{E}-06$ & 4.45E-06 & & & & \\
\hline $\mathrm{Y}$ & $1.72 \mathrm{E}-06$ & $1.95 \mathrm{E}-06$ & $5.85 \mathrm{E}-07$ & TOC, g/l & $8.55 \mathrm{E}-02$ & 7.74E-02 & $6.16 \mathrm{E}-02$ \\
\hline $\mathrm{Zn}$ & $5.86 \mathrm{E}-04$ & 4.34E-04 & $3.28 \mathrm{E}-04$ & UDS, g/l & $3.94 \mathrm{E}-01$ & 4.79E-01 & $3.43 \mathrm{E}-01$ \\
\hline $\mathrm{Zr}$ & 2.02E-03 & $7.10 \mathrm{E}-04$ & 7.86E-04 & Gallons & 120,000 & 120,000 & 120,000 \\
\hline
\end{tabular}

a. As of early March, 2002, all waste in the INTEC Tank Farm had been concentrated. Dilute and partially concentrated waste generated in the future will be collected in Tank WM-187. Current plans call for evaporation of waste in Tank WM-187 once per year from 2002 through 2007 and then in 2011. Table 5a shows projected compositions of waste in WM-187 that will be sent to the HLLWE in 2002, 2003 and 2004. 
Table 5. (continued) Representative compositions of SBW (b) concentrated feed. ${ }^{\mathrm{b}}$

\begin{tabular}{|c|c|c|c|c|c|c|c|}
\hline & WM-180 & WM-188 & WM-189 & & WM-180 & WM-188 & WM-189 \\
\hline \multirow[t]{3}{*}{ Gallons } & 276,000 & 275,200 & 279,900 & & $\mathrm{~mol} /$ liter & $\mathrm{mol} / \mathrm{liter}$ & $\mathrm{mol} /$ liter \\
\hline & & & & $\mathrm{Mn}$ & $1.48 \mathrm{E}-02$ & $1.64 \mathrm{E}-02$ & $2.03 \mathrm{E}-02$ \\
\hline & & & & $\mathrm{Hg}$ & $2.12 \mathrm{E}-03$ & $5.44 \mathrm{E}-03$ & $2.86 \mathrm{E}-03$ \\
\hline TOC, $\mathrm{g} / \mathrm{l}$ & 0.212 & 0.424 & 0.396 & Mo & $2.02 \mathrm{E}-04$ & $4.06 \mathrm{E}-04$ & $5.68 \mathrm{E}-05$ \\
\hline \multirow[t]{3}{*}{ UDS, g/l } & 0.246 & 3.738 & 3.988 & $\mathrm{Nd}$ & $1.50 \mathrm{E}-05$ & 4.19E-05 & $2.81 \mathrm{E}-05$ \\
\hline & & & & $\mathrm{Np}$ & $1.66 \mathrm{E}-05$ & $1.63 \mathrm{E}-05$ & $1.39 \mathrm{E}-05$ \\
\hline & $\mathrm{mol} /$ liter & $\mathrm{mol} / \mathrm{liter}$ & $\mathrm{mol} / \mathrm{liter}$ & $\mathrm{Ni}$ & $1.54 \mathrm{E}-03$ & 4.32E-03 & $5.67 \mathrm{E}-03$ \\
\hline \multirow[t]{2}{*}{$\mathrm{H}+$} & 1.06 & 2.99 & 2.51 & $\mathrm{Nb}$ & $1.63 \mathrm{E}-05$ & $6.61 \mathrm{E}-06$ & $1.97 \mathrm{E}-07$ \\
\hline & & & & $\mathrm{NO} 3$ & $5.57 \mathrm{E}+00$ & $6.50 \mathrm{E}+00$ & $6.84 \mathrm{E}+00$ \\
\hline $\mathrm{Al}$ & $6.96 \mathrm{E}-01$ & 5.83E-01 & $6.62 \mathrm{E}-01$ & $\mathrm{Pd}$ & $2.46 \mathrm{E}-05$ & $5.15 \mathrm{E}-06$ & 3.52E-06 \\
\hline $\mathrm{Am}$ & 7.60E-08 & $9.65 \mathrm{E}-08$ & $1.08 \mathrm{E}-07$ & $\mathrm{PO} 4$ & $1.44 \mathrm{E}-02$ & $4.53 \mathrm{E}-03$ & 7.07E-03 \\
\hline $\mathrm{Sb}$ & $6.69 \mathrm{E}-05$ & $8.08 \mathrm{E}-06$ & 2.83E-06 & $\mathrm{Pu}$ & $5.53 \mathrm{E}-06$ & $5.58 \mathrm{E}-06$ & $5.17 \mathrm{E}-06$ \\
\hline As & $5.24 \mathrm{E}-04$ & 4.41E-05 & $3.27 \mathrm{E}-05$ & $\mathrm{~K}$ & $2.06 \mathrm{E}-01$ & $1.57 \mathrm{E}-01$ & $2.10 \mathrm{E}-01$ \\
\hline $\mathrm{Ba}$ & $5.85 \mathrm{E}-05$ & $8.85 \mathrm{E}-05$ & $1.05 \mathrm{E}-04$ & $\operatorname{Pr}$ & 4.20E-06 & $1.17 \mathrm{E}-05$ & $7.85 \mathrm{E}-06$ \\
\hline $\mathrm{Be}$ & $8.15 \mathrm{E}-06$ & $2.18 \mathrm{E}-06$ & $8.83 \mathrm{E}-07$ & $\mathrm{Pm}$ & $1.53 \mathrm{E}-09$ & 4.27E-09 & 2.87E-09 \\
\hline B & $1.29 \mathrm{E}-02$ & 2.31E-02 & $2.80 \mathrm{E}-02$ & $\mathrm{Rh}$ & $1.84 \mathrm{E}-06$ & $5.12 \mathrm{E}-06$ & $3.44 \mathrm{E}-06$ \\
\hline $\mathrm{Br}$ & $1.53 \mathrm{E}-07$ & $6.18 \mathrm{E}-06$ & $9.14 \mathrm{E}-07$ & $\mathrm{Rb}$ & 3.64E-06 & $1.07 \mathrm{E}-05$ & 7.05E-06 \\
\hline $\mathrm{Cd}$ & 7.92E-04 & $6.33 \mathrm{E}-03$ & $8.86 \mathrm{E}-03$ & $\mathrm{Ru}$ & $1.31 \mathrm{E}-04$ & $3.79 \mathrm{E}-05$ & $1.71 \mathrm{E}-05$ \\
\hline $\mathrm{Ca}$ & 4.95E-02 & $5.98 \mathrm{E}-02$ & 7.11E-02 & $\mathrm{Sm}$ & $2.88 \mathrm{E}-06$ & $8.03 \mathrm{E}-06$ & $5.39 \mathrm{E}-06$ \\
\hline $\mathrm{Ce}$ & $4.96 \mathrm{E}-05$ & $2.36 \mathrm{E}-05$ & $1.72 \mathrm{E}-05$ & $\mathrm{Se}$ & $1.53 \mathrm{E}-04$ & $3.04 \mathrm{E}-06$ & $1.73 \mathrm{E}-06$ \\
\hline $\mathrm{Cs}$ & $8.12 \mathrm{E}-06$ & $2.44 \mathrm{E}-05$ & $1.64 \mathrm{E}-05$ & $\mathrm{Si}$ & $3.17 \mathrm{E}-07$ & $3.27 \mathrm{E}-03$ & 4.09E-03 \\
\hline $\mathrm{Cl}$ & $3.15 \mathrm{E}-02$ & 2.32E-02 & $3.06 \mathrm{E}-02$ & $\mathrm{Ag}$ & $5.55 \mathrm{E}-06$ & $2.08 \mathrm{E}-05$ & $2.02 \mathrm{E}-05$ \\
\hline $\mathrm{Cr}$ & $3.52 \mathrm{E}-03$ & $6.14 \mathrm{E}-03$ & $6.77 \mathrm{E}-03$ & $\mathrm{Na}$ & $2.16 \mathrm{E}+00$ & $1.35 \mathrm{E}+00$ & $1.84 \mathrm{E}+00$ \\
\hline Co & $2.02 \mathrm{E}-05$ & $1.73 \mathrm{E}-04$ & $1.14 \mathrm{E}-04$ & $\mathrm{Sr}$ & $1.25 \mathrm{E}-04$ & 2.91E-05 & $1.81 \mathrm{E}-05$ \\
\hline $\mathrm{Cu}$ & 7.32E-04 & $9.17 \mathrm{E}-04$ & $1.13 \mathrm{E}-03$ & $\mathrm{SO} 4$ & $7.34 \mathrm{E}-02$ & $4.51 \mathrm{E}-02$ & $5.69 \mathrm{E}-02$ \\
\hline Dy & $3.15 \mathrm{E}-10$ & $8.78 \mathrm{E}-10$ & $5.90 \mathrm{E}-10$ & $\mathrm{Tc}$ & $2.82 \mathrm{E}-06$ & $9.71 \mathrm{E}-06$ & $5.27 \mathrm{E}-06$ \\
\hline $\mathrm{Eu}$ & 3.09E-09 & $1.01 \mathrm{E}-08$ & 9.01E-09 & $\mathrm{Te}$ & $1.45 \mathrm{E}-06$ & 4.04E-06 & 2.72E-06 \\
\hline $\mathrm{F}$ & $4.98 \mathrm{E}-02$ & $1.13 \mathrm{E}-01$ & $1.10 \mathrm{E}-01$ & $\mathrm{~Tb}$ & 1.07E-09 & 2.97E-09 & $2.00 \mathrm{E}-09$ \\
\hline $\mathrm{Gd}$ & $1.86 \mathrm{E}-04$ & 7.52E-05 & $1.82 \mathrm{E}-06$ & $\mathrm{Tl}$ & 4.29E-05 & $1.00 \mathrm{E}-05$ & $1.42 \mathrm{E}-05$ \\
\hline $\mathrm{Ge}$ & 4.45E-09 & $2.53 \mathrm{E}-08$ & $9.74 \mathrm{E}-09$ & $\mathrm{Th}$ & $9.39 \mathrm{E}-11$ & $2.62 \mathrm{E}-10$ & $1.76 \mathrm{E}-10$ \\
\hline In & $6.74 \mathrm{E}-07$ & $1.88 \mathrm{E}-06$ & $1.26 \mathrm{E}-06$ & $\mathrm{Sn}$ & $4.31 \mathrm{E}-05$ & $2.31 \mathrm{E}-06$ & $6.75 \mathrm{E}-07$ \\
\hline I & $5.86 \mathrm{E}-07$ & $3.89 \mathrm{E}-06$ & $3.16 \mathrm{E}-06$ & $\mathrm{Ti}$ & $6.07 \mathrm{E}-05$ & $5.07 \mathrm{E}-05$ & $6.45 \mathrm{E}-05$ \\
\hline $\mathrm{Fe}$ & $2.28 \mathrm{E}-02$ & $2.61 \mathrm{E}-02$ & $2.68 \mathrm{E}-02$ & $\mathrm{U}$ & $3.54 \mathrm{E}-04$ & $5.22 \mathrm{E}-04$ & $5.67 \mathrm{E}-04$ \\
\hline $\mathrm{La}$ & $4.54 \mathrm{E}-06$ & $1.26 \mathrm{E}-05$ & 8.49E-06 & $\mathrm{V}$ & $9.69 \mathrm{E}-04$ & $1.26 \mathrm{E}-04$ & $1.50 \mathrm{E}-04$ \\
\hline $\mathrm{Pb}$ & $1.37 \mathrm{E}-03$ & $4.63 \mathrm{E}-03$ & $1.61 \mathrm{E}-03$ & $\mathrm{Y}$ & $3.46 \mathrm{E}-06$ & $9.63 \mathrm{E}-06$ & $6.47 \mathrm{E}-06$ \\
\hline $\mathrm{Li}$ & $3.56 \mathrm{E}-04$ & $3.53 \mathrm{E}-04$ & 4.61E-04 & $\mathrm{Zn}$ & $1.10 \mathrm{E}-03$ & $1.93 \mathrm{E}-03$ & $1.49 \mathrm{E}-03$ \\
\hline $\mathrm{Mg}$ & $1.26 \mathrm{E}-02$ & $8.18 \mathrm{E}-03$ & $1.03 \mathrm{E}-02$ & $\mathrm{Zr}$ & $6.64 \mathrm{E}-05$ & $1.78 \mathrm{E}-02$ & $2.10 \mathrm{E}-02$ \\
\hline
\end{tabular}

b. From C. M. Barnes, "Updated Sodium Bearing Waste Compositions for Treatment Simulations," INEEL Interoffice Memorandum, CMB-08-02, April 15, 2002. 
Table 5(b). (continued).

\begin{tabular}{|c|c|c|c|c|c|c|c|}
\hline & WM-180 & WM-188 & WM-189 & & WM-180 & WM-188 & WM-189 \\
\hline & $\mathrm{Ci} /$ liter & $\mathrm{Ci} /$ liter & Ci/liter & & $\mathrm{Ci} /$ liter & $\mathrm{Ci} / \mathrm{liter}$ & $\mathrm{Ci} /$ liter \\
\hline & Jan, 2016 & Jan, 2016 & Jan, 2016 & & Jan, 2016 & Jan, 2016 & Jan, 2016 \\
\hline Tl-208 & $3.35 \mathrm{E}-10$ & $1.13 \mathrm{E}-09$ & $6.55 \mathrm{E}-10$ & $\mathrm{Cm}-243$ & $1.02 \mathrm{E}-08$ & 3.45E-08 & $2.00 \mathrm{E}-08$ \\
\hline $\mathrm{Pb}-211$ & $2.76 \mathrm{E}-11$ & $9.29 \mathrm{E}-11$ & $5.40 \mathrm{E}-11$ & $\mathrm{Cm}-244$ & 2.71E-06 & $1.75 \mathrm{E}-06$ & $1.02 \mathrm{E}-06$ \\
\hline $\mathrm{Pb}-212$ & $9.46 \mathrm{E}-10$ & $3.19 \mathrm{E}-09$ & $1.85 \mathrm{E}-09$ & $\mathrm{Cm}-245$ & $1.46 \mathrm{E}-10$ & $4.91 \mathrm{E}-10$ & $2.85 \mathrm{E}-10$ \\
\hline Bi-211 & $2.76 \mathrm{E}-11$ & $9.29 \mathrm{E}-11$ & $5.40 \mathrm{E}-11$ & $\mathrm{Cm}-246$ & $9.46 \mathrm{E}-12$ & $3.19 \mathrm{E}-11$ & $1.85 \mathrm{E}-11$ \\
\hline Bi-212 & $9.46 \mathrm{E}-10$ & $3.19 \mathrm{E}-09$ & $1.85 \mathrm{E}-09$ & $\mathrm{H}-3$ & $1.02 \mathrm{E}-05$ & $1.33 \mathrm{E}-05$ & $1.03 \mathrm{E}-05$ \\
\hline Po-215 & $1.58 \mathrm{E}-11$ & $5.31 \mathrm{E}-11$ & $3.08 \mathrm{E}-11$ & Be-10 & $1.46 \mathrm{E}-12$ & $4.91 \mathrm{E}-12$ & $2.85 \mathrm{E}-12$ \\
\hline Po-216 & $9.46 \mathrm{E}-10$ & $3.19 \mathrm{E}-09$ & $1.85 \mathrm{E}-09$ & $\mathrm{C}-14$ & 5.91E-11 & 4.04E-06 & $1.16 \mathrm{E}-10$ \\
\hline Po-218 & $6.31 \mathrm{E}-12$ & $2.12 \mathrm{E}-11$ & $1.23 \mathrm{E}-11$ & Se-79 & 2.13E-07 & 7.17E-07 & $4.16 \mathrm{E}-07$ \\
\hline Rn-219 & 2.76E-11 & $9.29 \mathrm{E}-11$ & $5.40 \mathrm{E}-11$ & $\mathrm{Rb}-87$ & 1.42E-11 & $4.78 \mathrm{E}-11$ & $2.78 \mathrm{E}-11$ \\
\hline Rn-220 & $9.46 \mathrm{E}-10$ & $3.19 \mathrm{E}-09$ & 1.85E-09 & $\mathrm{Sr}-90$ & $9.72 \mathrm{E}-03$ & $5.63 \mathrm{E}-02$ & $3.12 \mathrm{E}-02$ \\
\hline Rn-222 & $6.31 \mathrm{E}-12$ & $2.12 \mathrm{E}-11$ & $1.23 \mathrm{E}-11$ & Y-90 & $9.72 \mathrm{E}-03$ & $5.63 \mathrm{E}-02$ & $3.12 \mathrm{E}-02$ \\
\hline Ra-223 & 2.76E-11 & $9.29 \mathrm{E}-11$ & $5.40 \mathrm{E}-11$ & Zr-93 & $1.06 \mathrm{E}-06$ & $3.58 \mathrm{E}-06$ & $2.08 \mathrm{E}-06$ \\
\hline Ra-224 & $9.46 \mathrm{E}-10$ & $3.19 \mathrm{E}-09$ & $1.85 \mathrm{E}-09$ & Nb-93m & $9.07 \mathrm{E}-07$ & 3.05E-06 & 1.77E-06 \\
\hline Ra-226 & $6.31 \mathrm{E}-12$ & $2.12 \mathrm{E}-11$ & $1.23 \mathrm{E}-11$ & $\mathrm{Nb}-94$ & 5.52E-07 & $1.86 \mathrm{E}-06$ & $1.08 \mathrm{E}-06$ \\
\hline Ac-225 & $1.89 \mathrm{E}-13$ & $6.37 \mathrm{E}-13$ & $3.70 \mathrm{E}-13$ & Tc-98 & $1.26 \mathrm{E}-12$ & $4.25 \mathrm{E}-12$ & $2.47 \mathrm{E}-12$ \\
\hline Ac-227 & $2.76 \mathrm{E}-11$ & $9.29 \mathrm{E}-11$ & $5.40 \mathrm{E}-11$ & Tc-99 & $1.04 \mathrm{E}-05$ & $1.92 \mathrm{E}-05$ & $9.30 \mathrm{E}-06$ \\
\hline Th-227 & $2.72 \mathrm{E}-11$ & $9.16 \mathrm{E}-11$ & $5.32 \mathrm{E}-11$ & Ru-106 & $5.91 \mathrm{E}-11$ & $1.74 \mathrm{E}-10$ & $9.34 \mathrm{E}-11$ \\
\hline Th-228 & $9.46 \mathrm{E}-10$ & $3.19 \mathrm{E}-09$ & $1.85 \mathrm{E}-09$ & Rh-102 & $1.89 \mathrm{E}-11$ & $6.37 \mathrm{E}-11$ & $3.70 \mathrm{E}-11$ \\
\hline Th-229 & $1.89 \mathrm{E}-13$ & $6.37 \mathrm{E}-13$ & $3.70 \mathrm{E}-13$ & Rh-106 & 5.91E-11 & $1.74 \mathrm{E}-10$ & $9.34 \mathrm{E}-11$ \\
\hline Th-230 & $4.72 \mathrm{E}-10$ & $1.59 \mathrm{E}-09$ & $9.22 \mathrm{E}-10$ & Pd-107 & $7.88 \mathrm{E}-09$ & $2.66 \mathrm{E}-08$ & $1.54 \mathrm{E}-08$ \\
\hline Th-231 & $1.02 \mathrm{E}-08$ & $3.45 \mathrm{E}-08$ & $2.00 \mathrm{E}-08$ & Cd-113m & 8.67E-07 & 2.92E-06 & $1.70 \mathrm{E}-06$ \\
\hline Th-234 & $1.02 \mathrm{E}-08$ & 3.45E-08 & $2.00 \mathrm{E}-08$ & In-115 & 4.73E-17 & $1.59 \mathrm{E}-16$ & $9.25 \mathrm{E}-17$ \\
\hline $\mathrm{Pa}-231$ & 4.73E-11 & $1.59 \mathrm{E}-10$ & $9.25 \mathrm{E}-11$ & Sn-121m & $2.72 \mathrm{E}-08$ & $9.16 \mathrm{E}-08$ & $5.32 \mathrm{E}-08$ \\
\hline Pa-233 & $1.42 \mathrm{E}-06$ & $4.78 \mathrm{E}-06$ & $2.78 \mathrm{E}-06$ & Sn-126 & 2.01E-07 & $6.77 \mathrm{E}-07$ & 3.93E-07 \\
\hline Pa-234m & $1.02 \mathrm{E}-08$ & 3.45E-08 & $2.00 \mathrm{E}-08$ & Sb-125 & $2.44 \mathrm{E}-07$ & $1.08 \mathrm{E}-06$ & 9.72E-07 \\
\hline $\mathrm{Pa}-234$ & $1.30 \mathrm{E}-11$ & $4.38 \mathrm{E}-11$ & $2.54 \mathrm{E}-11$ & Sb-126m & 2.01E-07 & $6.77 \mathrm{E}-07$ & $3.93 \mathrm{E}-07$ \\
\hline U-232 & $2.10 \mathrm{E}-09$ & $9.16 \mathrm{E}-09$ & $9.11 \mathrm{E}-09$ & Sb-126 & $2.80 \mathrm{E}-08$ & $9.43 \mathrm{E}-08$ & $5.47 \mathrm{E}-08$ \\
\hline U-233 & $2.74 \mathrm{E}-10$ & $1.20 \mathrm{E}-09$ & $1.19 \mathrm{E}-09$ & Te-125m & $5.91 \mathrm{E}-08$ & $1.99 \mathrm{E}-07$ & $1.16 \mathrm{E}-07$ \\
\hline U-234 & $9.14 \mathrm{E}-07$ & $1.36 \mathrm{E}-06$ & $1.33 \mathrm{E}-06$ & I-129 & $1.33 \mathrm{E}-08$ & $8.87 \mathrm{E}-08$ & $7.24 \mathrm{E}-08$ \\
\hline U-235 & $2.38 \mathrm{E}-08$ & 3.49E-08 & $3.60 \mathrm{E}-08$ & Cs-134 & $5.05 \mathrm{E}-08$ & $6.80 \mathrm{E}-07$ & 5.93E-07 \\
\hline U-236 & 3.75E-08 & $5.20 \mathrm{E}-08$ & $6.14 \mathrm{E}-08$ & Cs-135 & 4.34E-07 & $1.46 \mathrm{E}-06$ & $8.48 \mathrm{E}-07$ \\
\hline U-237 & 3.93E-09 & $1.71 \mathrm{E}-08$ & $1.70 \mathrm{E}-08$ & Cs-137 & $2.16 \mathrm{E}-02$ & $6.11 \mathrm{E}-02$ & $3.55 \mathrm{E}-02$ \\
\hline U-238 & $2.38 \mathrm{E}-08$ & 4.07E- 08 & 4.02E-08 & Ba-137m & 1.71E-02 & $5.75 \mathrm{E}-02$ & $3.34 \mathrm{E}-02$ \\
\hline Np-237 & 4.98E-07 & $3.52 \mathrm{E}-06$ & $2.42 \mathrm{E}-06$ & Ce-142 & $1.46 \mathrm{E}-11$ & 4.91E-11 & 2.85E-11 \\
\hline Np-238 & 3.51E-11 & $1.18 \mathrm{E}-10$ & $6.86 \mathrm{E}-11$ & Ce-144 & $2.88 \mathrm{E}-12$ & $8.19 \mathrm{E}-12$ & 4.06E-12 \\
\hline Np-239 & 1.02E-08 & 3.45E-08 & $2.00 \mathrm{E}-08$ & Pr-144 & $2.88 \mathrm{E}-12$ & $8.19 \mathrm{E}-12$ & 4.06E-12 \\
\hline Pu-236 & $5.52 \mathrm{E}-11$ & $1.86 \mathrm{E}-10$ & $1.08 \mathrm{E}-10$ & Pm-146 & 4.73E-09 & $1.59 \mathrm{E}-08$ & $9.25 \mathrm{E}-09$ \\
\hline Pu-238 & $5.94 \mathrm{E}-04$ & 7.04E-04 & $6.49 \mathrm{E}-04$ & Pm-147 & $2.68 \mathrm{E}-06$ & $9.03 \mathrm{E}-06$ & $5.24 \mathrm{E}-06$ \\
\hline $\mathrm{Pu}-239$ & $9.89 \mathrm{E}-05$ & $9.14 \mathrm{E}-05$ & $7.38 \mathrm{E}-05$ & Sm-151 & $1.50 \mathrm{E}-04$ & 5.05E-04 & $2.93 \mathrm{E}-04$ \\
\hline $\mathrm{Pu}-240$ & $5.12 \mathrm{E}-06$ & 1.67E-05 & $9.16 \mathrm{E}-06$ & Eu-150 & $5.52 \mathrm{E}-12$ & 1.86E-11 & $1.08 \mathrm{E}-11$ \\
\hline $\mathrm{Pu}-241$ & $6.70 \mathrm{E}-05$ & $2.86 \mathrm{E}-04$ & $2.07 \mathrm{E}-04$ & Eu-152 & 6.31E-07 & $2.12 \mathrm{E}-06$ & $1.23 \mathrm{E}-06$ \\
\hline $\mathrm{Pu}-242$ & 3.86E-09 & $4.23 \mathrm{E}-08$ & $1.04 \mathrm{E}-08$ & Eu-154 & $1.93 \mathrm{E}-05$ & 1.02E-04 & 7.49E-05 \\
\hline Am-241 & $8.97 \mathrm{E}-05$ & $1.03 \mathrm{E}-04$ & $1.00 \mathrm{E}-04$ & Eu-155 & $1.30 \mathrm{E}-05$ & $2.20 \mathrm{E}-05$ & $1.86 \mathrm{E}-05$ \\
\hline Am-242m & 7.09E-09 & 2.39E-08 & $1.39 \mathrm{E}-08$ & Ho-166m & $2.25 \mathrm{E}-11$ & 7.57E-11 & $4.39 \mathrm{E}-11$ \\
\hline Am-242 & 7.09E-09 & $2.39 \mathrm{E}-08$ & $1.39 \mathrm{E}-08$ & & & & \\
\hline Am-243 & $1.02 \mathrm{E}-08$ & $3.45 \mathrm{E}-08$ & $2.00 \mathrm{E}-08$ & Co-60 & $8.29 \mathrm{E}-07$ & $1.09 \mathrm{E}-05$ & $1.15 \mathrm{E}-05$ \\
\hline Cm-242 & 5.91E-09 & $1.99 \mathrm{E}-08$ & $1.16 \mathrm{E}-08$ & Ni-63 & $2.21 \mathrm{E}-05$ & 5.91E-05 & $4.90 \mathrm{E}-05$ \\
\hline
\end{tabular}


Table 6. Representative composition of suspended solids in SBW ${ }^{\mathrm{a}}$

\begin{tabular}{|c|c|c|c|}
\hline & Wt \% & & $\mathrm{Ci} / \mathrm{g}$ solids \\
\hline Aluminum & 5.85 & Am-241 & $3.1 \mathrm{E}-7$ \\
\hline Antimony & 0.004 & Co-60 & $3.6 \mathrm{E}-8$ \\
\hline Arsenic & $<7.1 \mathrm{E}-4$ & Cs-134 & $2.6 \mathrm{E}-7$ \\
\hline Barium & 0.0034 & Cs-137 & $2.6 \mathrm{E}-4$ \\
\hline Beryllium & $<1.9 \mathrm{E}-4$ & Eu-154 & $4.3 \mathrm{E}-7$ \\
\hline Boron & $<0.051$ & I-129 & 0 \\
\hline Cadmium & 0.018 & Np-237 & $3.4 \mathrm{E}-9$ \\
\hline Calcium & 0.43 & $\mathrm{Pu}-238$ & $8.8 \mathrm{E}-5$ \\
\hline Cerium & 0.0043 & $\mathrm{Pu}-239$ & $1.3 \mathrm{E}-5$ \\
\hline Cesium & 0.052 & Sb-125 & $3.4 \mathrm{E}-6$ \\
\hline Chromium & 0.068 & Total Sr & $6.2 \mathrm{E}-5$ \\
\hline Cobalt & $<0.0015$ & Tc-99 & $2.4 \mathrm{E}-8$ \\
\hline Copper & 0.014 & U-234 & $4.3 \mathrm{E}-9$ \\
\hline Gadolinium & 0.008 & $\mathrm{U}-235$ & $8.9 \mathrm{E}-11$ \\
\hline Iron & 2.01 & U-236 & $1.7 \mathrm{E}-10$ \\
\hline Lead & 0.052 & U-238 & $3.8 \mathrm{E}-11$ \\
\hline Lithium & $<0.016$ & & \\
\hline Magnesium & 0.14 & & \\
\hline Manganese & 0.16 & & \\
\hline Mercury & $<0.89$ & & \\
\hline Molybdenum & 0.036 & & \\
\hline Nickel & 0.028 & & \\
\hline Niobium & $<1.0$ & & \\
\hline Palladium & $<0.076$ & & \\
\hline Phosphorus & 5.43 & & \\
\hline Potassium & 1.47 & & \\
\hline Ruthenium & 0.036 & & \\
\hline Selenium & $<0.13$ & & \\
\hline Silicon & 2.09 & & \\
\hline Silver & 0.005 & & \\
\hline Sodium & 7.82 & & \\
\hline Strontium & 0.0022 & & \\
\hline Sulfur & 0.51 & & \\
\hline Thallium & $<0.14$ & & \\
\hline Tin & 0.21 & & \\
\hline Titanium & 0.096 & & \\
\hline Uranium & 0.035 & & \\
\hline Vanadium & $<0.001$ & & \\
\hline Zinc & 0.02 & & \\
\hline Zirconium & 2.8 & & \\
\hline Chloride & 0.091 & & \\
\hline Fluoride & 0.0033 & & \\
\hline Nitrate & 43.4 & & \\
\hline \multicolumn{4}{|c|}{$\begin{array}{l}\text { a. Composition of WM-180 suspended solids; from J. D. Christian, Composition and Simulation of the WM-180 } \\
\text { Sodium-Bearing Waste at the Idaho Nuclear Technology and Engineering Center, INEEL/EXT-2001-00600, } \\
\text { May 2001. }\end{array}$} \\
\hline
\end{tabular}


Table 7. Representative compositions of heel solids from SBW Tanks. ${ }^{a}$

\begin{tabular}{|c|c|c|c|c|c|c|c|}
\hline & WM-182 & WM-183 & WM-188 & & WM-182 & WM-183 & WM-188 \\
\hline & $\mathrm{mg} / \mathrm{kg}$ & $\mathrm{mg} / \mathrm{kg}$ & $\mathrm{mg} / \mathrm{kg}$ & & $\mathrm{mg} / \mathrm{kg}$ & $\mathrm{mg} / \mathrm{kg}$ & $\mathrm{mg} / \mathrm{kg}$ \\
\hline $\mathrm{Al}$ & 21,880 & 24,911 & 35,406 & $\mathrm{Sr}$ & 9 & 11 & \\
\hline $\mathrm{Sb}$ & 14 & 32 & 33 & $\mathrm{SO}_{4}$ & 33,240 & 13,647 & \\
\hline As & 281 & 56 & 351 & $\mathrm{~S}$ & 8,743 & 2,849 & \\
\hline $\mathrm{Ba}$ & 127 & 24 & 12,542 & $\mathrm{Tc}$ & & 0 & \\
\hline $\mathrm{Be}$ & 1 & 1 & 0.2 & $\mathrm{Tl}$ & 17 & 14 & 783 \\
\hline $\mathrm{B}$ & 150 & 182 & 482 & $\mathrm{Sn}$ & 4,072 & 1,466 & \\
\hline $\mathrm{Cd}$ & 325 & 142 & 1,189 & $\mathrm{Ti}$ & 650 & 711 & \\
\hline $\mathrm{Ca}$ & 1,765 & 1,868 & 5,630 & $\mathrm{U}$ & $4.62 \mathrm{E}+01$ & $1.93 \mathrm{E}-01$ & \\
\hline $\mathrm{Ce}$ & 21 & 20 & & $\mathrm{~V}$ & 13 & 11 & 6 \\
\hline $\mathrm{Cs}$ & 42 & 9 & & $\mathrm{Zn}$ & 179 & 148 & 126 \\
\hline $\mathrm{Cl}$ & 2,015 & 1,308 & & $\mathrm{Zr}$ & 101,470 & 34,867 & 64,844 \\
\hline $\mathrm{Cr}$ & 552 & 949 & 1,341 & Total & 467,177 & 500,167 & 157,952 \\
\hline $\mathrm{Co}$ & 9 & 9 & 9 & TOC & & & 12 \\
\hline $\mathrm{Cu}$ & 298 & 166 & & & & & \\
\hline $\mathrm{F}$ & 14,800 & 4,373 & & & $\mathrm{mCi} / \mathrm{g}$ & $\mathrm{mCi} / \mathrm{g}$ & $\mathrm{mCi} / \mathrm{g}$ \\
\hline $\mathrm{Gd}$ & 53 & 170 & & Am-241 & $8.46 \mathrm{E}-04$ & $2.45 \mathrm{E}-04$ & $2.11 \mathrm{E}-04$ \\
\hline $\mathrm{Fe}$ & 4,476 & 17,967 & 5,769 & Sb-125 & $5.77 \mathrm{E}-02$ & $2.90 \mathrm{E}-03$ & $1.12 \mathrm{E}-02$ \\
\hline $\mathrm{Pb}$ & 369 & 274 & 647 & Cs-134 & $6.64 \mathrm{E}-03$ & 5.89E-04 & $7.97 \mathrm{E}-03$ \\
\hline $\mathrm{Li}$ & 6 & 4 & & Cs-137 & $4.50 \mathrm{E}+00$ & $8.68 \mathrm{E}-01$ & $2.44 \mathrm{E}+00$ \\
\hline $\mathrm{Mg}$ & 410 & 434 & & Co-60 & $2.14 \mathrm{E}-04$ & & $6.30 \mathrm{E}-04$ \\
\hline $\mathrm{Mn}$ & 565 & 740 & 758 & $\mathrm{Cm}-244$ & $2.84 \mathrm{E}-06$ & & \\
\hline $\mathrm{Hg}$ & 310 & 324 & 1,566 & Eu-154 & $1.48 \mathrm{E}-03$ & $7.56 \mathrm{E}-04$ & $5.43 \mathrm{E}-04$ \\
\hline Mo & 2,495 & 694 & 2,518 & I-129 & $2.22 \mathrm{E}-07$ & $9.03 \mathrm{E}-08$ & $9.51 \mathrm{E}-04$ \\
\hline $\mathrm{Ni}$ & 309 & 417 & 427 & $\mathrm{~Np}-237$ & $1.68 \mathrm{E}-06$ & $1.76 \mathrm{E}-06$ & $2.85 \mathrm{E}-06$ \\
\hline $\mathrm{Nb}$ & 1,279 & 623 & 5,101 & $\mathrm{Nb}-95$ & & & $3.68 \mathrm{E}-03$ \\
\hline $\mathrm{NO}_{3}$ & 70,720 & 174,955 & & $\mathrm{Pu}-238$ & $1.93 \mathrm{E}-02$ & $4.00 \mathrm{E}-03$ & $7.56 \mathrm{E}-03$ \\
\hline $\mathrm{Pd}$ & 5,766 & 1,444 & & $\mathrm{Pu}-239$ & $1.47 \mathrm{E}-03$ & $1.25 \mathrm{E}-03$ & 4.30E-04 \\
\hline $\mathrm{PO}_{4}$ & 97,806 & 139,740 & & Sr-90 & $2.29 \mathrm{E}-01$ & $1.82 \mathrm{E}-01$ & $5.46 \mathrm{E}+00$ \\
\hline $\mathrm{P}$ & 9,586 & 4,607 & 16,422 & Tc-99 & $2.63 \mathrm{E}-03$ & $3.29 \mathrm{E}-05$ & $4.49 \mathrm{E}-03$ \\
\hline $\mathrm{K}$ & 7,050 & 10,900 & & H-3 & $1.15 \mathrm{E}-05$ & & \\
\hline $\mathrm{Ru}$ & 829 & 2,126 & 273 & U-234 & $2.40 \mathrm{E}-06$ & $3.30 \mathrm{E}-06$ & $2.00 \mathrm{E}-05$ \\
\hline $\mathrm{Se}$ & 91 & 13 & 1,720 & U-235 & $2.61 \mathrm{E}-07$ & $9.29 \mathrm{E}-08$ & $1.97 \mathrm{E}-07$ \\
\hline $\mathrm{Si}$ & 43,920 & 35,344 & & U-236 & $3.05 \mathrm{E}-07$ & $3.40 \mathrm{E}-08$ & $2.07 \mathrm{E}-07$ \\
\hline $\mathrm{Ag}$ & 65 & 220 & 9 & U-238 & $3.83 \mathrm{E}-08$ & $6.91 \mathrm{E}-08$ & $1.18 \mathrm{E}-07$ \\
\hline $\mathrm{Na}$ & 30,400 & 21,400 & & & & & \\
\hline
\end{tabular}


Table 8. Representative compositions of NGLW. ${ }^{\text {a }}$

\begin{tabular}{|c|c|c|c|c|c|c|c|}
\hline \multicolumn{4}{|c|}{ MLLW \& LLW NGLW } & \multicolumn{4}{|c|}{ TRU NGLW } \\
\hline & moles/liter & & Ci/liter & & moles/liter & & Ci/liter \\
\hline $\mathrm{H}+$ & $5.12 \mathrm{E}+00$ & $\mathrm{H}-3$ & $6.05 \mathrm{E}-09$ & $\mathrm{H}+$ & $4.01 \mathrm{E}+00$ & Co-60 & $2.37 \mathrm{E}-08$ \\
\hline $\mathrm{Al}$ & $1.43 \mathrm{E}-01$ & Co-60 & $3.62 \mathrm{E}-08$ & $\mathrm{Al}$ & $8.48 \mathrm{E}-03$ & Sr-90 & $1.44 \mathrm{E}-03$ \\
\hline $\mathrm{Sb}$ & $1.52 \mathrm{E}-04$ & Sr-90 & 4.92E-04 & $\mathrm{Sb}$ & $6.08 \mathrm{E}-05$ & Y-90 & $1.44 \mathrm{E}-03$ \\
\hline As & $9.90 \mathrm{E}-07$ & Y-90 & 4.92E-04 & As & $1.20 \mathrm{E}-03$ & Tc-99 & $2.60 \mathrm{E}-09$ \\
\hline $\mathrm{Ba}$ & $2.43 \mathrm{E}-05$ & $\mathrm{Nb}-94$ & $6.86 \mathrm{E}-08$ & $\mathrm{Ba}$ & $1.20 \mathrm{E}-04$ & $\mathrm{I}-129$ & $5.78 \mathrm{E}-07$ \\
\hline $\mathrm{Be}$ & $5.05 \mathrm{E}-06$ & Tc-99 & $7.86 \mathrm{E}-10$ & $\mathrm{Be}$ & $5.40 \mathrm{E}-07$ & Cs-134 & $1.32 \mathrm{E}-08$ \\
\hline $\mathrm{B}$ & $1.94 \mathrm{E}-03$ & $\mathrm{Ru}-106$ & $1.08 \mathrm{E}-10$ & $\mathrm{Cd}$ & $7.76 \mathrm{E}-06$ & Cs-137 & $1.76 \mathrm{E}-03$ \\
\hline $\mathrm{Cd}$ & $6.77 \mathrm{E}-05$ & Rh-106 & $1.08 \mathrm{E}-10$ & $\mathrm{Cr}$ & 4.39E-04 & $\mathrm{Ba}-137 \mathrm{~m}$ & $1.65 \mathrm{E}-03$ \\
\hline $\mathrm{Ca}$ & $1.02 \mathrm{E}-03$ & $\mathrm{Sb}-125$ & $1.11 \mathrm{E}-07$ & Co & $2.88 \mathrm{E}-06$ & $\mathrm{Eu}-152$ & $1.59 \mathrm{E}-08$ \\
\hline $\mathrm{Cr}$ & $1.21 \mathrm{E}-03$ & $\mathrm{I}-129$ & $1.64 \mathrm{E}-07$ & $\mathrm{Cs}$ & $7.26 \mathrm{E}-07$ & $\mathrm{Eu}-154$ & $7.85 \mathrm{E}-07$ \\
\hline $\mathrm{Co}$ & $1.08 \mathrm{E}-05$ & Cs-134 & $1.34 \mathrm{E}-08$ & $\mathrm{Cu}$ & $3.32 \mathrm{E}-05$ & $\mathrm{Eu}-155$ & $2.15 \mathrm{E}-07$ \\
\hline $\mathrm{Cs}$ & $2.20 \mathrm{E}-07$ & Cs-137 & $5.32 \mathrm{E}-04$ & $\mathrm{~Pb}$ & $2.17 \mathrm{E}-05$ & & \\
\hline $\mathrm{Cu}$ & $6.01 \mathrm{E}-04$ & $\mathrm{Ce}-144$ & $3.03 \mathrm{E}-11$ & $\mathrm{Hg}$ & $5.55 \mathrm{E}-05$ & U-232 & $1.98 \mathrm{E}-10$ \\
\hline $\mathrm{Fe}$ & $2.44 \mathrm{E}-03$ & Pr-144 & $2.52 \mathrm{E}-11$ & $\mathrm{Mn}$ & $1.06 \mathrm{E}-03$ & U-234 & $3.50 \mathrm{E}-08$ \\
\hline $\mathrm{Pb}$ & $1.25 \mathrm{E}-04$ & Eu-152 & 8.63E-08 & $\mathrm{Ni}$ & $1.84 \mathrm{E}-04$ & U-235 & $9.19 \mathrm{E}-10$ \\
\hline $\mathrm{Hg}$ & $2.56 \mathrm{E}-04$ & Eu-154 & $4.25 \mathrm{E}-06$ & $\mathrm{~K}$ & $1.17 \mathrm{E}-02$ & U-236 & $1.47 \mathrm{E}-09$ \\
\hline $\mathrm{Mn}$ & $8.21 \mathrm{E}-03$ & Eu-155 & $8.17 \mathrm{E}-08$ & $\mathrm{Se}$ & $1.98 \mathrm{E}-06$ & U-238 & $1.02 \mathrm{E}-09$ \\
\hline $\mathrm{Ni}$ & 4.70E-04 & & & $\mathrm{Ag}$ & $6.88 \mathrm{E}-06$ & $\mathrm{~Np}-237$ & $6.25 \mathrm{E}-08$ \\
\hline $\mathrm{K}$ & $1.22 \mathrm{E}-02$ & U-232 & $6.50 \mathrm{E}-11$ & $\mathrm{Na}$ & $5.78 \mathrm{E}-02$ & $\mathrm{Pu}-238$ & $1.89 \mathrm{E}-05$ \\
\hline $\mathrm{Se}$ & 7.14E-07 & U-234 & $1.15 \mathrm{E}-08$ & $\mathrm{Tl}$ & $6.42 \mathrm{E}-07$ & $\mathrm{Pu}-239$ & $2.56 \mathrm{E}-06$ \\
\hline $\mathrm{Ag}$ & $1.53 \mathrm{E}-05$ & U-235 & $3.02 \mathrm{E}-10$ & $\mathrm{U}$ & $1.40 \mathrm{E}-05$ & $\mathrm{Pu}-240$ & $3.00 \mathrm{E}-07$ \\
\hline $\mathrm{Na}$ & $1.26 \mathrm{E}-01$ & U-236 & $4.81 \mathrm{E}-10$ & $\mathrm{~V}$ & $2.90 \mathrm{E}-06$ & $\mathrm{Pu}-241$ & $5.44 \mathrm{E}-06$ \\
\hline $\mathrm{Tl}$ & $2.60 \mathrm{E}-07$ & U-238 & $3.34 \mathrm{E}-10$ & $\mathrm{Zn}$ & $2.71 \mathrm{E}-04$ & $\mathrm{Pu}-242$ & $5.48 \mathrm{E}-10$ \\
\hline $\mathrm{U}$ & $9.11 \mathrm{E}-05$ & $\mathrm{~Np}-237$ & $2.05 \mathrm{E}-08$ & $\mathrm{Cl}$ & $3.74 \mathrm{E}-03$ & Am-241 & $2.84 \mathrm{E}-06$ \\
\hline $\mathrm{V}$ & $1.36 \mathrm{E}-05$ & $\mathrm{Pu}-238$ & $6.20 \mathrm{E}-06$ & $\mathrm{~F}$ & $4.00 \mathrm{E}-03$ & & \\
\hline $\mathrm{Zn}$ & $3.30 \mathrm{E}-03$ & $\mathrm{Pu}-239$ & $8.41 \mathrm{E}-07$ & $\mathrm{SO} 4$ & $3.95 \mathrm{E}-03$ & Total TRU & $2.47 \mathrm{E}-05$ \\
\hline $\mathrm{Zr}$ & $1.51 \mathrm{E}-03$ & $\mathrm{Pu}-240$ & $9.86 \mathrm{E}-08$ & NO3 & $4.10 \mathrm{E}+00$ & & \\
\hline $\mathrm{Cl}$ & $1.05 \mathrm{E}-03$ & $\mathrm{Pu}-241$ & $1.78 \mathrm{E}-06$ & & & & \\
\hline $\mathrm{F}$ & $5.88 \mathrm{E}-02$ & $\mathrm{Pu}-242$ & $1.80 \mathrm{E}-10$ & TOC, g/liter & $1.45 \mathrm{E}+00$ & & \\
\hline $\mathrm{SO} 4$ & $1.82 \mathrm{E}-02$ & Am-241 & $9.33 \mathrm{E}-07$ & UDS, g/liter & 7.53E-01 & & \\
\hline $\mathrm{NO} 3$ & $5.64 \mathrm{E}+00$ & & & & & & \\
\hline $\mathrm{PO} 4$ & $2.70 \mathrm{E}-04$ & Total TRU & $8.09 \mathrm{E}-06$ & & & & \\
\hline TOC, g/liter & $9.97 \mathrm{E}+00$ & & & & & & \\
\hline UDS, g/liter & $6.95 \mathrm{E}+00$ & & & & & & \\
\hline
\end{tabular}


Table 9. Miscellaneous mass balance assumptions.

\begin{tabular}{|c|c|}
\hline Feed Evaporators & - Batch process terminates when solution reaches a specific gravity of 1.33 \\
\hline Acid Fractionator & - Bottoms stream is $12 \mathrm{M}$ nitric acid \\
\hline SBW Feed Rate & - 960,000 gal of SBW processed in 3 years and 200 operating days/year \\
\hline Reformer & $\begin{array}{l}\text { - } 600^{\circ} \mathrm{C} \text { operating temperature } \\
\text { - } 12 \text { psia operating pressure } \\
\text { - } \text { Feeds: Granular sugar equivalent to two times the amount required to } \\
\text { react with the acid in the } \mathrm{SBW} \text { to produce } \mathrm{CO}_{2} \text { and } \mathrm{H}_{2} \mathrm{O} \text {; carbon and } \\
\text { oxygen rates such that off-gas is } 1 \% \mathrm{H}_{2} \text { and reformer is adiabatic; steam } \\
\text { such that off-gas is } 84 \% \mathrm{H}_{2} \mathrm{O} \\
\text { - } 0.5 \% \text { carry-over of all feed species into reformer off-gas } \\
\text { - } 1 \% \text { carry-over of } \mathrm{Al}_{2} \mathrm{O}_{3}, \mathrm{SiO}_{2} \text { and } \mathrm{Fe}_{2} \mathrm{O}_{3}, 19 \% \text { carryover of all other } \\
\text { reformer solid products into the offgas } \\
\text { - Sufficient silica and alumina additives to result in } 80 \% \text { of the } \mathrm{Na} \text { in the } \\
\text { waste producing sodium nephaline, } \mathrm{Na}_{2} \mathrm{O} \mathrm{Al}_{2} \mathrm{O}_{3} 2 \mathrm{SiO}_{2} \text {, with the } \\
\text { remainder of the sodium in the ash as carbonate } \\
\text { - Reformer ash product contains } 4 \% \text { carbon }\end{array}$ \\
\hline Quench Rate & - Rate such that quench liquid is $20 \mathrm{wt} \%$ total solids \\
\hline Caustic Scrubber & - 5 liters caustic quench per $\mathrm{m}^{3}$ gas \\
\hline Caustic Scrub Blowdown & $\bullet \quad 0.5 \%$ \\
\hline Condenser & $\begin{array}{l}\text { - Temperature set so that effluent water rate equal to water in the SBW } \\
\text { feed plus water formed from sugar decomposition } \\
\text { - } 4 \% \text { entrainment }\end{array}$ \\
\hline HEME & - $100 \%$ efficiency removing entrained water \\
\hline Oxidizer preheater & - $1000^{\circ} \mathrm{C}$ temperature \\
\hline Oxidizer & $\begin{array}{l}\text { - Oxygen rate based on } 20 \% \text { excess of the stoichiometric requirement to } \\
\text { completely oxidize all } \mathrm{CO}, \mathrm{H}_{2} \mathrm{O} \text { and } \mathrm{H}_{2} \mathrm{~S}\end{array}$ \\
\hline Oxidizer effluent cooler & • $\quad$ Temperature $105^{\circ} \mathrm{C}$ \\
\hline GAC Bed & - $\quad 99.9 \% \mathrm{Hg}$ removal efficiency \\
\hline
\end{tabular}




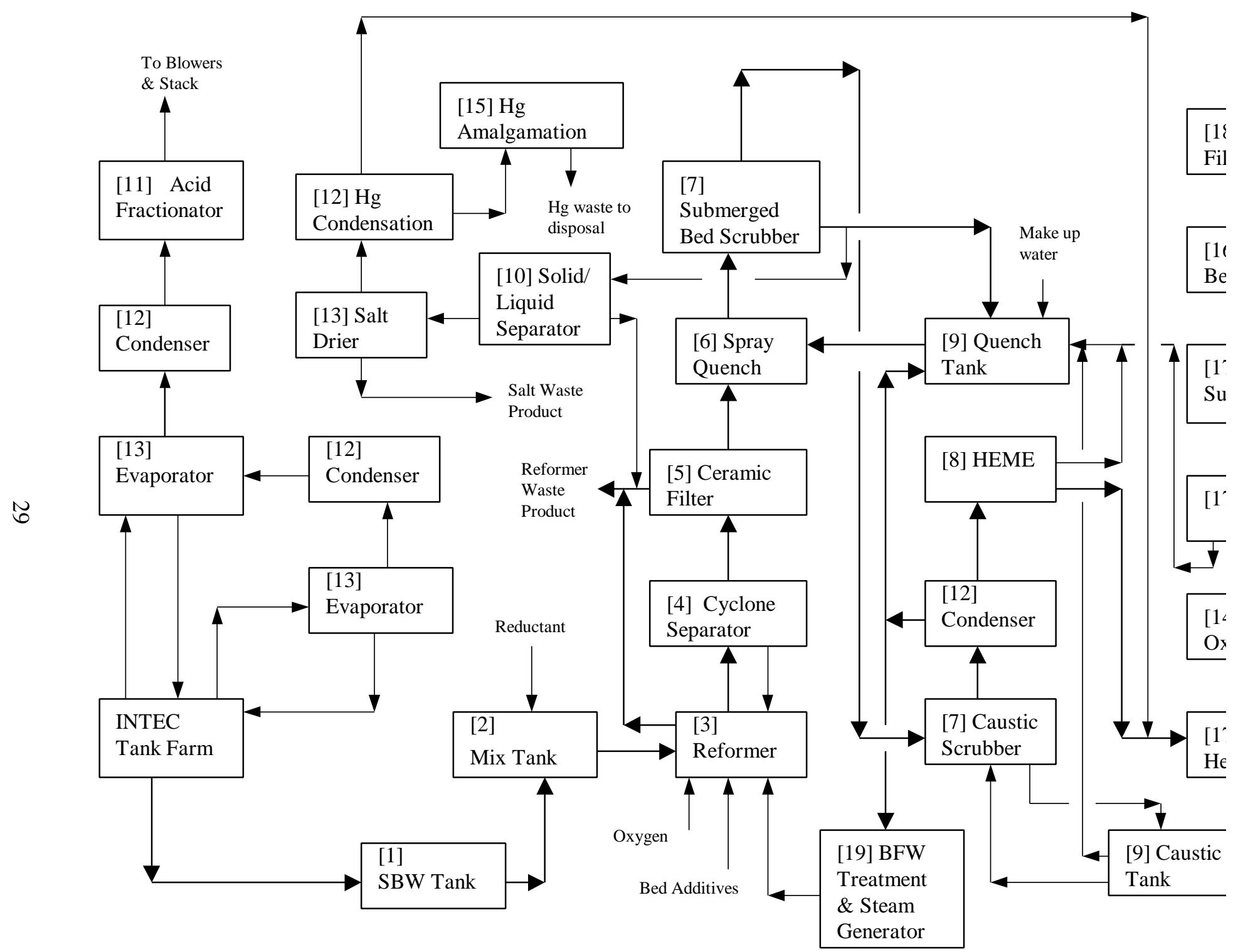

Figure 1. Process Configuration. 


\section{REFERENCES}

Barnes, C.M. (2000a), File named "Dir Vit Unit Operations.doc," An attachment to Lotus Notes memo to D.D. Taylor of INEEL, 10/19.

Barnes, C.M. (2000b), Feed Composition for Sodium-Bearing Waste Treatment Process, INEEL/EXT2000-01378, Revision 0, October, pp. 12-16.

Patterson, M. (1999), Light Duty Utility Arm Deployment in Tank WM-188, INEEL/EXT-99-01302, December.

Schindler, R. E. (1998), Evaporation of Blends of HLLWE Condensate with CPP-603 Basin Water, INEEL Letter to F.S. Ward, SCHI-26-98, November 18, p.9.

Soelberg, Nick (2001), Personal communication to D.D. Taylor of INEEL, January 18. 